\title{
Bank Power, Block Ownership, Boards and Financial Distress Likelihood: An Investigation of Spanish Listed Firms
}

\begin{abstract}
We investigate the effects of bank power, block ownership and board independence on the likelihood of financial distress. Using a matched sample design, we find that firms in which banks have power are more likely than their counterparts to enter financial distress. However, the bank power effects are moderated by block ownership and board independence. Specifically, on the one hand, financial distress due to bank power is lower for firms with greater ownership by pressure resistant blockholders and such blockholders appear to be the largest blockholder in the firm. The bank power effects are also lower in firms with greater outside directors and this appears to be primarily driven by proprietary directors than independent directors. On the other, we document evidence suggesting that the bank power effects are magnified for firms in which the board chair is a proprietary director aligned to non-financial blockholders or CEO/Chair, suggesting that banks might partly influence decisions via board chairs. Overall, the findings are consistent with bank power actions being detrimental to the firm, but the extent to which such actions harm the firm depends on the monitoring intentions of blockholders and/or board of directors. These findings have important implications for policymakers.
\end{abstract}

Keywords: Corporate governance; Bank power; board independence; block ownership; financial distress likelihood

JEL Codes: G30; G32; G33 


\section{Bank power, Governance and Distress}

\section{Introduction}

The aftermath of the 2007-2009 global financial crisis witnessed widespread financial distress of nonfinancial firms across countries, with huge effects on entire economies [International Monetary Fund (IMF), 2012]. While the causes were mainly blamed on macroeconomic factors (see Taylor, 2009; Erkens et al., 2012), the monitoring role of boards and large shareholders was severely questioned (see United Nations, 2010; Aebi et al., 2012). The criticisms reflect the well-established view that effective corporate governance is critical for performance, including reducing financial distress (Dowell et al., 2011). However, studies examining the impact of board and ownership structures on financial distress have been inconclusive (see Elloumi and Gueyle, 2001; Fich and Slezak, 2008; Donker et al., 2009; Dowell et al., 2011; Abdullah et al., 2016). A shortcoming of these studies is that they do not consider a critical factor in the life of the firm - the role of banks. Although existing literature documents the importance of banks in the resolution of financial distress (see Kawai et al., 1996; Berlin et al., 1996; Peek and Rosengren, 2005), their role in the likelihood of financial distress remains largely unexplored. Yet, a strand of studies documents that, compared to their counterparts, firms in which banks have power, in particular hold both debt and equity, have lower value (Morck et al., 2000; Lin et al., 2009; Tribo and Casasola-Martinez, 2010; Luo et al., 2011) and pay higher interest charges on bank loans (Weinstein and Yafeh, 1998; Degryse and Van Cayseele, 2000; Agrawal and Elston, 2001; Luo et al., 2011). These findings have been interpreted as indications of rent extraction by the bank.

In this paper, we attempt to fill this gap in the literature by examining the governance role of powerful banks on financial distress in Spanish firms, a setting in which banks provide both debt and equity finance to the same firm. Franks and Mayer (2001) and Tribo et al. (2007) argue that this dual role gives banks considerable power to influence firm decisions even if they are not the largest shareholder-we refer to this hereinafter as bank power. Specifically, our focus is to explore the effects of bank power on the likelihood of financial distress. We also analyse, drawing from the multiple blockholder literature (e.g., Pagano and Roell, 1998; Bolton and von Thadden, 1998) and board literature in general (e.g., Dowell et al., 2011; Mangena et al., 2012), whether and how the bank power effects on financial distress are moderated by block ownership and board structure. This literature suggests that blockholders and boards respond to actions that threaten firm survival. These issues are important given that financial distress is a precursor for bankruptcy which is harmful to stakeholders (Dowell et al., 2011; Hernandez-Tinoco and Wilson, 2013) and 


\section{Bank power, Governance and Distress}

has consequences for the stability of the financial sector due to contagion effects and the entire economy (IMF, 2012).

There are strong reasons for viewing banks as having substantial effects on financial distress. First, they provide debt finance that firms need for long-term growth, and often offer support via short-term maturity loans to help fund short term activities (Agarwal and Elston, 2001). In addition, they have the legal rights in cases of firms defaulting on obligations or violating debt covenants (Kroszner and Strahan, 2001). Second, in contextual settings such as Spain (so do Germany, Italy, Japan and others), banks are also allowed, in addition to their lending business, to directly hold equity in the same firm (Franks and Mayer, 2001). Thus, they also have voting rights as shareholders, and these voting rights are magnified by their holding of proxy votes for other (minority) shareholders (see Franks and Mayer, 1998, 2001; Tribo and Casasola-Martinez, 2010). All this taken together, banks have considerable power, which they are known to use to influence board or CEO appointments and influencing firm decisions (see Franks and Mayer, 2001; Tribo and Casasola-Martinez, 2010). In this context, their position in the firm is analogous to what Bebchuk et al. (2000) label controlling minority shareholders, that is, they have power to control firm decisions even when they are not the largest shareholders.

The manner by which this power is deployed has consequences for financial distress. On the one hand, banks could use power to better monitor management actions (Diamond, 1984; MahrtSmith, 2006). As lenders, they have privileged access to firm-specific information (Diamond, $1984 ; 1991$ ) which they can use to monitor and protect their lending portfolio. As equity providers, they have a residual claim on profits, hence the incentive to enhance firm-value (Mahrt-Smith, 2006). To the extent that banks are exposed as both lender and equity-holder, it would be in their interests to use their power to ensure firm survival and reducing the impact on their balance sheets. They are better positioned to achieve this, because, as insiders, they are well-informed about the firm's financial position and have power to take actions before problems become serious. In contrast, Rajan (1992), Petersen and Rajan (1994) and Berlin et al. (1996) argue that banks use their power to extract rents. These works suggest that due to information asymmetry in the lending market, banks exploit informational advantages to maximise their revenue from the firm via higher charges. The presence of asymmetric information creates adverse selection problems, leading to higher switching costs and making it difficult for firms to switch lenders (Schenone, 2010). This presents banks with opportunities to charge higher interest (Degryse and Van Cayseele, 2000; 


\section{Bank power, Governance and Distress}

Agrawal and Elston, 2001). Kashyap et al. (2008) argue that the incentives are exacerbated because banks (and their managers) are evaluated based on the lending income they generate. This encourages them to take strategies that enhance their short-term performance at the expense of the borrower's long-term performance (Stein, 1989).

Empirically, some studies document evidence of effective monitoring (e.g., Kang and Shivdasani, 1997; Ivashina et al., 2009; Pan and Tian, 2015), while others suggest rent extraction or reduced monitoring intensity by the banks (e.g., Weinstein and Yafeh, 1998; Morck et al., 2000; Tribo et al., 2007; Lin et al., 2009; Luo et al., 2011). Thus, the extent to which bank power alleviates or precipitates financial distress remains unclear. We explore this issue using a matched sample of listed Spanish financially distressed and non-financially distressed firms. We extend the analyses to understand whether block ownership and board structure influence the bank powerfinancial distress relationship. We draw insights from the multiple blockholders literature that builds models of contests and coalitions that have implications for the firm (see Pagano and Roell, 1998; Bolton and von Thadden, 1998; Maury and Pajuste, 2005). In line with this literature, we suggest that to the extent that bank actions harm the firm, blockholders will monitor and contest such actions. The constructs of block ownership we examine are size of ownership, type of blockholder (i.e. pressure sensitive, pressure resistant and non-financial blocks) and dispersion of blockholders in the firm. Further, we also draw from studies that focus on the importance of board structure when firm survival is threatened (Dowell et al., 2011; Mangena et al., 2012). To the extent that banks extract rents (Rajan, 1992; Petersen and Rajan, 1994; Barucci and Mattesini, 2008), the existence of bank power can be viewed as a threat. In this case, we focus on board independence as proxied by $\mathrm{CEO} /$ Chair duality, proprietary director board chair and outside directors (both proprietary and independent directors). ${ }^{1}$ In our analyses, however, we accept that banks may form coalitions with these mechanisms to reduce monitoring intensity (Pagano and Roell, 1998; Bennedsen and Wolfenzon, 2000). Thus, bank power effects on financial distress must depend on monitoring incentives of blockholders or boards.

We find a positive relationship between bank power and financial distress likelihood - that is, firms in which banks have power are more likely than their counterparts to enter financial distress. We also find evidence linking blockholder power and board independence to reduced

\footnotetext{
${ }^{1}$ In Spain outside directors are of two types: proprietary directors appointed by the largest shareholders to represent their interests and independent directors appointed to represent the interests of minority shareholders [see Unified Corporate Governance Code, 2013].
} 


\section{Bank power, Governance and Distress}

financial distress due to bank power. Thus, the bank power effects on financial distress are moderated by these two governance mechanisms. Specifically, we find that for firms with high block ownership, financial distress due to bank power is less likely and such effects are primarily due to pressure resistant blockholders. These are also more likely to be the largest blockholder in the firm. We also find that the bank power effects are more pronounced for firms with proprietary director board chair (particularly those aligned to non-financial blocks) or CEO/Chair whereas the opposite occurs for firms with more outside directors. Similar to blockholders, the effects of outside directors are due to pressure resistant proprietary directors. Overall, the results suggest that bank power increases financial distress likelihood, but the effects are moderated by governance mechanisms. These results are robust to several additional tests.

Our work offers several contributions to the literature. First, we extend studies examining the impact of bank power on firm outcomes such as performance (Morck et al., 2000; Lin et al., 2009), R\&D investments (Tribo et al., 2007), executive perks (Luo et al., 2011) and investment efficiency (Pan and Tian, 2015). We differ from these studies in that we examine, not only the effects of bank power, but also how bank power interacts with other governance structures to influence organisational outcomes. Our findings suggesting that bank power effects depend on monitoring by blockholders and independent boards are an extension to these prior works. Second, we add to the literature on the role of multiple blockholders in monitoring (e.g., Maury and Pajuste, 2005; Konijn et al., 2011; Basu et al., 2016, 2017). Specifically, we complement this literature by showing that in a setting where banks have power, blockholders and boards provide the mechanisms to monitor bank actions. Third, we also open an interesting avenue on the role of proprietary director chairs. Whereas prior literature focuses on the CEO/Chair dichotomy, we extend this by examining the role of the proprietary director chair and our results suggesting that proprietary director chairs may be detrimental to the firm are new and interesting. Finally, our work relates to studies that examine the role of banks in the resolution of financial distress (e.g., Hoshi et al., 1990; Berlin et al., 1996; Hower, 2016). We differ by our focus on financial distress likelihood. In this case, we inform these studies by showing that banks may as well bear responsibility for financial distress.

The rest of the paper proceeds as follows. In Section 2, we discuss the contextual setting in Spain. In Section 3, we discuss the theory and develop our hypotheses. We next describe our data 


\section{Bank power, Governance and Distress}

and empirical models in Section 4, and then present and discuss the findings in Section 5. Finally, we end by providing concluding remarks in Section 6.

\section{Institutional Setting}

Spain is a natural setting for our study for two reasons. First, Spanish firms suffered the most during and in the aftermath of the financial crisis compared to other countries, and over a prolonged period (see IMF, 2012). From the firm's perspective, the financial crisis was an unexpected exogenous turbulence that exposed firms to higher risk of failure. Dowell et al. (2011) and Mangena et al. (2012), among others, argue that it is in these turbulence environments that corporate governance is apposite and can be better understood. Second, the Spanish governance system offers a unique and interesting context in which to understand how control dynamics in the firm affects outcomes, including financial distress (see also Tribo et al., 2007). These control dynamics (discussed below) could provide some insights into why some firms went into financial distress while others did not.

In terms of the corporate governance system, Spain falls within the insider-dominated model, yet some of its features are like the outsider-dominated model (see Tribo et al., 2007). As in countries such as Germany, Italy and Japan, banks play a major role in the financial markets and are important in the governance of other firms. In many Spanish firms, banks provide both debt finance and equity to the same firm, sometimes as significant (and controlling) shareholders (Tribo et al., 2007; Ruiz-Mallorqui and Santana-Martin, 2009; Tribo and Casasola-Martinez, 2010). In relation to this, Crespi-Cladera and Garcia-Cestona (2002) document that banks directly own on average $5.2 \%$ of equity in non-financial firms. Similarly, Azofra et al. (2007) show that nearly half of Spanish listed firms have a bank shareholder owning about $10 \%$ of equity. Further, banks also hold proxy votes for minority shareholders (Franks and Mayer, 2001; Tribo and CasasolaMartinez, 2010). Thus, together, banks' voting rights are often above their cash flow rights. According to Franks and Mayer (2001), while their equity holdings may be modest, the combination of debt, equity (including proxy votes) endows them with considerable control power over firm decisions. Tribo and Casasola-Martinez (2010) suggest that banks do use this power to appoint their own directors to boards. This set-up makes banks insiders and well-informed about the firm and places them in better and stronger position to monitor managers (Diamond, 1984; 


\section{Bank power, Governance and Distress}

1991) or alternatively, to extract rents from the firms (Rajan, 1992; Bertin et al., 1996; Tribo and Casasola-Martinez, 2010).

On balance, given the dual role, the monitoring incentive should dominate as banks would be motivated to protect both their loan and equity holding portfolios. This is particularly important because the Spanish Insolvency Act 22/2003 (Article 93) [BOE (Official State Bulletin), 2003] classifies shareholders with debt claims and owning at least $5 \%$ of equity as subordinated creditors. This means that they are not preferred in cases of bankruptcy. However, according to GarciaPosada and Mora-Sanguinetti (2014), banks circumvent the Act by biasing their lending towards secured loans. In this context, bank debt secured over assets is the most common form of lending, and banks use foreclosures to recover debts when firms are in difficulty.

A second important feature of the governance system is that share ownership is concentrated in a few blockholders, including families, individuals, corporates and financial institutions (such as banks, insurance funds, mutual funds, pension funds) (Crespi-Cladera and Garcia-Cestona, 2002; Tribo et al., 2007; Ruiz-Mallorqui and Santana-Martin, 2009). On average, these blockholders, hold about 33.5\% of equity of Spanish listed firms (CVNM, 2018) and are allowed to, and do, appoint outside directors (called proprietary directors) to represent their interests on the board (as provided for in the Unified Corporate Governance (UCG) Code, 2013). According to the CVNM (2018), proprietary directors in Spanish listed firms account for about $33.6 \%$ of directorships. In this context, like dual banks, these blockholders can be viewed as well-informed players in the firm. To the extent that banks seek to extract rents from firms, these blockholders and their proprietary directors are likely to be critical in monitoring. As work on multiple blockholders shows, non-controlling blockholders can reduce the rent extraction actions of the controlling blockholder (e.g., Maury and Pajuste, 2005; Konijn et al., 2011; Basu et al., 2016, 2017). Indeed, Leech and Manjon (2002) point that in Spain blockholders do collaborate via agreements pooling their voting rights to monitor firms' decisions. In line with this, the CVNM (2018) documents that such agreements affect $31.9 \%$ of share capital of listed firms.

Finally, like the Anglo-American model, the Spanish law provides for a unitary board structure, with a majority of outside directors (see Capital Companies Law, 2010; UCG Code, 2013). Outside directors are distinguished into two main types-proprietary directors and independent directors. As noted above, proprietary directors (about 33.6\% of directors) are appointed by the largest shareholders to represent their interests. The independent directors (about 


\section{Bank power, Governance and Distress}

$42.7 \%$ of directors) are appointed to represent the interests of minority shareholders. Both these directors have a fiduciary duty to monitor as well as to advise management (Pucheta-Martinez and Garcia-Meca, 2014). However, because they represent interests of constituents whose objectives may differ, their incentives to monitor may also differ. Another feature of board structure in Spain is that CEO/Chair duality is a common practice. CNMV (2018) shows that nearly $48.9 \%$ of listed firms have duality of functions.

\section{Theory and hypotheses}

Traditionally, the governance literature has focused substantial attention on understanding the agency problems between dispersed shareholders and managers. However, a recent body of research documents that in many countries (e.g., Japan, Spain, Germany and others), firms are owned by a few large shareholders and firms with controlling blockholders are a common phenomenon (see Franks and Mayer, 2001; Maury and Pajuste, 2005; Basu et al., 2017). In such countries, Shleifer and Vishny (1997) and Burkart et al. (1997) argue that the agency problems are instead between the controlling blockholders and minority shareholders. Bebchuk et al. (2000) note that such agency problems are acute when the controlling blockholder is a controlling minority blockholder - that is, they are not the largest blockholder, but their voting rights exceed their cash-flow rights allowing them to control the firm. Whereas the controlling minority blockholder may use their control power to either monitor or extract rents, Bertrand et al. (2002) document evidence of substantial expropriation in firms with a controlling minority blockholder. We apply this to develop our hypotheses.

\subsection{Bank power and financial distress likelihood}

The position of banks in Spain is analogous to that of the controlling minority shareholders (see Section 2). While their equity holdings are modest (Leech and Manjon, 2002; Azofra et al., 2007), they have control power derived from being both lenders and equity holders in the same firm, coupled by their holding of proxy votes for other shareholders. This set up gives them power to appoint their own directors to the boards (Franks and Mayer, 2001; Tribo and Casasola-Martinez, 2010). This power makes them better informed as insiders and can permit stringent monitoring, reducing suboptimal decisions and enhancing performance (e.g., Diamond, 1984; 1991; Ivashina et al., 2009). Not only do they have incentives to protect their large lending portfolios, they are 
also residual claimants on the firm's profits, thus magnifying their incentives to monitor (Agrawal and Elston, 2001; Mahrt-Smith, 2006; Pan and Tian, 2015). This is critical because if the firm fails, the bank would suffer huge losses which it has to realise on the balance sheet with implications for capital adequacy ratios and its stability (Peek and Rosengren, 2005).

On the dark side, however, the power might exacerbate conflicts between the bank, as debtholder, and other shareholders. As suggested in Morck et al. (2000) and Mahrt-Smith (2006) among others, because the banks' lending business typically dominates its equity positions, they may find it beneficial to maximise their lending portfolio at the expense of the firm. For instance, they may charge above market interest rates on bank loans maximising their revenue income from the firm at the expense of long-term firm performance (Weinstein and Yafeh, 1998; Degryse and Van Cayseele, 2000). Kashyap et al. (2008) suggest that this is particularly attractive because the banks' (and its managers) performance is evaluated, in part, based on income generated from lending. Consequently, as argued in Stein (1989), this may lead bank managers to behave myopically, taking strategies that earn high short-term revenue income for the bank, but at the expense of the borrower's long-term performance.

The empirical evidence is similarly contrasting in its conclusions. There are studies documenting bank power as beneficial to the firm. For example, bank power is shown to associate with higher asset restructuring in periods of poor performance (Kang and Shivdasani, 1997), improve value creation in M\&A activities (Ivashina et al., 2009) and facilitate value enhancing investment choices (Pan and Tian, 2015). Yet a growing body of work points towards rent extraction by the bank. For instance, banks are shown to encourage firms to take additional debt at above market interest rates (Weinstein and Yafeh, 1998; Degryse and Van Cayseele, 2000; Agrawal and Elston, 2001). Pinkowitz and Williamson (2001) show evidence consistent with banks encouraging firms to keep large cash balances whilst inducing them to use bank loans to fund capital projects and using the cash to pay the debts. Luo et al. (2011) document that firms in which banks have power pay higher executive perks as well as higher interest on bank debt. Other studies report that equity ownership by banks is associated with lower value (e.g., Morck et al., 2000; Limpaphayom and Polwitoon, 2004; Lin et al., 2009; Tribo and Casasola-Martinez, 2010).

Although the evidence on rent extraction appears to dominate, the extent to which such bank actions precipitate financial distress needs to be understood in the context of the cost-benefit tradeoff to the bank. Financial distress (and potentially bankruptcy) would not only end the revenue 
income streams but could also result in substantial capital losses for the bank. Given this, we would expect the bank to balance the implied costs of financial distress with the benefits of extracting higher interest income from the firm. This is particularly the case because the Insolvency Act (Article 93) (BOE, 2003) classifies debt claims as subordinated if the bank also owns at least 5\% of firm equity. This means that in the event of firm bankruptcy, the bank is not a preferred creditor - thus, the loss to the bank could be huge. However, the empirical work suggests banks extract rents (see Tribo et al., 2007; Ruiz-Mallorqui and Santana-Martin, 2009; Tribo and Casasola-Martinez, 2010). One reason is that banks circumvent the Act by offering debt secured over assets and using foreclosures to recover debts if firms are in difficulty. This strategy reduces the costs of financial distress to the bank (Garcia-Posada and Mora-Sanguinetti, 2014). This leads us to predict that:

H1: Bank power increases the likelihood that a firm enters financial distress.

\subsection{The moderating role of block ownership and board independence on bank power effects}

In Hypothesis 1, we assume the absence of mechanisms to monitor the actions of the powerful bank. This is the common assumption that most studies examining the impact of bank power on firm outcomes take (see Morck et al., 2000; Limpaphayom and Polwitoon, 2004; Tribo et al., 2007; Lin et al., 2009; Luo et al., 2011; Pan and Tian, 2015). However, multiple blockholder studies such as Pagano and Roell (1998), Maury and Pajuste (2005), and Basu et al. (2016), among others, suggest that blockholders provide invaluable monitoring that could curb rent extraction by the controlling power. In addition, the board structure literature argues that in the face of threats to firm survival, boards become more vigilant and monitor (Fama and Jensen, 1983; Dowell et al., 2011; Mangena et al., 2012). Thus, to the extent that bank power presents a setting where firm survival is threatened, blockholders and boards would monitor and contest actions that harm the firm. We draw from this literature to build our hypotheses in the following sections.

\subsubsection{Bank power-block ownership effects on financial distress likelihood}

The motivation for blockholders to monitor the bank (as the controlling power) derives, not only from a desire to protect their investments (Hoskisson et al., 2002), but also from the fact that they are rivals for control. Pagano and Roell (1998) and Bolton and von Thadden (1998) demonstrate that these blockholders are critical in curbing actions that harm the firm. In our case, blockholder 


\section{Bank power, Governance and Distress}

monitoring implies that bank rent extraction cannot persist and harm the firm-it is contested. The blockholders can, for example, threaten to (i) take-over the firm (see Cremers and Nair, 2005), (ii) sell their shares (John and Kedia, 2006) or (iii) pressure managers to switch firm business to other banks (Schenone, 2010). This can be achieved by pooling their voting rights to act as a group (see Leech and Manjon, 2002; Crespi and Renneboog, 2010) or as individual blockholders if they have enough large ownership (Maury and Pajuste, 2005; Basu et al., 2017). However, as modelled in the Pagano and Roell (1998) and Maury and Pajuste (2005), the opportunity also exists for the bank to form coalitions with the blockholders to reduce monitoring intensity. This is possible if the blockholders have business ties with the firm, a common feature in the Spanish context (see Tribo et al., 2007; Ruiz-Mallorqui and Santana-Martin, 2009). For example, the bank may encourage managers to offer favourable supply contracts to the blockholders' business interests (Pagano and Roell, 1998; Tribo and Martinez, 2010).

The ability of blockholders to monitor and contest the bank must depend on blockholder power (i.e., size of ownership, blockholder dispersion) and their monitoring intentions (see Tribo et al., 2007; Crespi and Renneboog, 2010; Basu et al., 2016). The size of block ownership matters as it confers substantial voting control of the firm. It carries with it the ability to contest decisions or even to threaten certain actions, leading to change of direction (Cremers and Nair, 2005; John and Kedia, 2006; Schenone, 2010) and therefore could deter rent extraction. Thomsen et al. (2006) and Cornett et al. (2007), among others, argue that blockholder intervention or contest depends on their monitoring intentions. Consequently, they divide blockholders into types based on their monitoring objectives, in particular, nonfinancial and financial blockholders. Fama and Jensen (1983) and Thomsen et al. (2006) suggest that nonfinancial blockholders (individual, family, corporates) are associates and have incentives to extract private benefits. Some evidence shows that these blockholders are prone to lower firm value (Thomsen and Pedersen, 2000; Maury and Pajuste, 2005) or forming coalitions with the controlling power and lowering firm value (Basu et al., 2017). On the contrary, Anderson and Reed (2003) show that they are beneficial to valuethey find, in particular, that family firms perform better than counterparts.

Meanwhile, financial blockholders (investment funds, pension funds, insurance funds, mutual funds) are suggested as effective monitors. However, their monitoring intentions also differ. Accordingly, Cornett et al. (2007) and Bhattacharya and Graham (2009), among others, further classify them into 'pressure-sensitive' blockholders (banks, insurance funds) and 'pressure- 


\section{Bank power, Governance and Distress}

resistant' blockholders (pension funds, mutual funds). Pressure-sensitive blockholders have either existing or potential business ties with firms, which compromises their monitoring. In contrast pressure-resistant blockholders only have investment interest in the firm and are therefore unconstrained in their monitoring (Bhattacharya and Graham, 2009). Cornett et al. (2007) and Manzaneque et al. (2016) show, respectively, that pressure-resistant blockholders enhance firm performance and reduce financial distress, while Bhattacharya and Graham (2009) document that pressure-sensitive blockholders have the opposite effect.

With regards to blockholder dispersion, the literature argues and documents that dispersion reduces monitoring effectiveness. Tribo et al. (2007) argue that a large dispersion makes coordination and consensus on decisions among blockholders more difficult. As a result, their power to monitor and contest value destroying actions is weakened. This presents opportunities for the controlling power to extract rents. Studies such as Tribo et al. (2007), Konijn et al. (2011) and Basu et al. (2016) document evidence to support this. They show that blockholder dispersion is negatively related to firm performance. These discussions lead us to predict:

H2: The extent to which bank power increases the likelihood of financial distress depends on blockholder power and their monitoring incentives.

\subsubsection{Bank power-board independence effects on financial distress likelihood}

A well-documented view is that boards are a critical in the governance of firms. Fama and Jensen (1983) and Jensen (1993) argue that boards are at the apex of the firm and are bestowed the fiduciary duty to monitor. Within this context, the repeated argument is that the willingness and ability of boards to monitor the firm is a function of their independence (Fama and Jensen; 1983; Jensen, 1993; Dowell et al., 2011; Black and Kim, 2012; Mangena et al., 2012). Two factors that are apposite for board independence are board leadership and outside directors.

In terms of leadership, the Spanish context presents two dimensions - the CEO/Chair duality and the proprietary director chair. The CEO/Chair duality refers to whether the roles of board chair and CEO are combined or separated. On the one hand, role duality bequeaths too much power to one person, hindering the board's ability to monitor the CEO (Jensen, 1993; Brickley et al., 1997) and creating opportunities for the CEO to extract rents (Fama and Jensen, 1983). If role duality weakens board monitoring, rent extraction by the bank may thrive in firms with CEO/Chair. The bank could capitalise and motivate the CEO to implement strategies that benefit itself-for 


\section{Bank power, Governance and Distress}

instance it could commit to influence CEO pay decisions. Luo et al. (2011) document higher executive perks in firms with bank power and that such firms also pay higher interest rates on bank loans. On the other hand, role duality is argued to provide a unified power of command that improves board efficiency (Anderson and Anthony, 1986; Bach and Smith, 2007). This power is a resource that puts the $\mathrm{CEO} / \mathrm{Chair}$ in a stronger position to lead and enhance firm survival. The motivation for the $\mathrm{CEO} / \mathrm{Chairs}$ to work effectively with the board to ensure firm survival is much stronger as they would typically have undiversifiable personal wealth tied up in the firm (Easterbrook, 1984). In the event of financial distress, the CEO/Chair would suffer substantial reputation damage in the market for directorships (Easterbrook, 1984; Dowell et al., 2011). They would also be hurt through loss in the value of their shares. These should provide incentives to mitigate the effects of bank power actions. In support of this, Dowell et al. (2011) document that firms with $\mathrm{CEO} / \mathrm{Chair}$ are more likely to survive following financial distress.

The implications of the proprietary director board chair have not, as far as we are aware, been addressed in the literature. Prior work has focused on the CEO/Chair dichotomy. However, although proprietary directors are non-executive, they represent the interests of the most important (or powerful) shareholders - the blockholders (Garcia-Sanchez et al., 2014; Fuente et al., 2017). In this context, we consider the appointment of a proprietary director board chair as important as having a combined chair and CEO. In concentrated ownership settings, the blockholders are viewed as insiders and using their power to benefit themselves at the expense of the minority shareholders (Burkart et al., 1997; Bertrand et al., 2002; Tribo et al., 2007). Thus, a proprietary director chair who represents the controlling blockholder would have strong influence over management decisions as well as board decisions. Hence, this can be viewed as creating a powerful individual who on one hand can enhance board monitoring of management and on the other can hinder board monitoring intensity in order to serve the interests of their blockholders. In support of this, Franks and Mayer (1998) document evidence, in the context of Germany, suggesting that banks were able to influence decisions by using their appointed supervisory board chair.

In relation to outside directors, the conventional wisdom is that these are better monitors and are the first line of defence against rent extraction (Fama and Jensen, 1983; Jensen, 1993). Not only do they monitor, they also bring greater critical resources (e.g., experience, knowledge and networks) for the CEO to draw advice (Black and Kim, 2012; Mangena et al., 2012). To this extent, outside directors should reduce financial distress due to bank power. For example, they can use 


\section{Bank power, Governance and Distress}

their knowledge and networks to link the firm to a varied source of external funding and reducing the firm's reliance on a single bank. Prior studies provide evidence showing the important monitoring role that these directors perform to enhance firm value (see Dowell et al., 2011; Black and Kim, 2012), and particularly in settings where firm survival is threatened (see Donker et al., 2009; Dowell et al., 2011). Others have shown that outside directors improve the quality of reporting (García Osma and Gill-de-Abornoz Noguer, 2007; Pucheta-Martinez and Garcia-Meca, 2014; Fuente et al., 2017).

As earlier noted, in Spain, outside directors are of two types - independent and proprietary directors (see Section 2). While both monitor (Pucheta-Martinez and Garcia-Meca, 2014; Fuente et al., 2017), the role of proprietary directors needs to be understood in the context of the monitoring objectives of their appointing blockholders. Thus, one should expect these directors to protect or drive the interests of their blockholders. For instance, monitoring by directors representing pressure-sensitive blockholders or nonfinancial blockholders may be inhibited by business ties with the firm. To the extent that the bank, as the controlling power, influences the business ties, these proprietary directors may vote with the bank or management (Brickley et al., 1997). In contrast, directors appointed by pressure-resistant blockholders would monitor given the arm's length relationship with the firm. Pucheta-Martinez and Garcia-Meca (2014) and Fuente et al. (2017) document that pressure-resistant directors are associated with quality reporting. Manzaneque et al. (2016) show that these directors are related to lower financial distress. García Osma and Gill-de-Abornoz Noguer (2007) reveal that board independence is associated with less earnings management while Dowell et al. (2011) shows that the likelihood of surviving financial distress increases with independent directors. The preceding discussions lead us to predict:

H3: The extent to which bank power increases the likelihood of financial distress depends on board independence.

\section{Research Design}

\subsection{Data and sample construction}

We draw our data from nonfinancial firms listed on the Spanish Stock Exchange (SSE) for the period spanning years 2007-2015. Prior to 2005, Spanish listed firms were using local accounting standards instead of international accounting standards. Therefore, using data post-2005 allows us 


\section{Bank power, Governance and Distress}

to circumvent measurement problems relating to the use of financial data generated from using different accounting standards. Our dataset starts in 2007 instead of 2005 because of the way we construct the measure for financial distress as explained below.

We follow prior work (e.g., Opler and Titman, 1994; Pindado et al., 2008; IMF, 2012) and define financial distress as the ability of the firm to meet its financial obligations. To develop our financial distress measure, we adopt the approach developed in Pindado et al. (2008). This measure is ex-ante and is based on two main conditions. First, earnings before interest and taxes, depreciation and amortization (EBITDA) must be lower than the interest expense (i.e., interest cover ratio) for two consecutive years. The second condition is that the firm's market value suffers negative growth for two consecutive years. Both conditions need to be satisfied for a firm to be considered financially distressed. Opler and Titman (1994) use a similar measure of financial distress, but their conditions are based on sales growth and stock returns. Both Opler and Titman (1994) and Pindado et al. (2008) argue that the negative market value growth is important in order to eliminate downturns in performance that are not long-term in nature. Similarly, the interest cover ratio is required to eliminate firms that are healthy but experience negative market value growth due to prior optimistic market expectations. This measure of financial distress has also been applied in prior studies (e.g., Hernandez-Tinoco and Wilson, 2013; Manzaneque et al., 2016).

To apply Pindado's model, we collected EBITDA and interest expense data from the Sistema de Analisis de Balance Ibericos (SABI) database and stock market values from the SSE. We identified a total of 198 firms that met our financial distress definition. Upon inspection, some firms appeared multiple times because they remained classified as in financial distress in subsequent years. As our focus is on financial distress likelihood, we eliminate all subsequent firmyears so that a firm appears once in our sample - that is the first year in which it is classified as in distress. This process yielded 109 financially distressed firms. We next adopt a matched-pair research design to build our final sample (Hosmer and Lemeshow, 2000; Peasnell et al., 2001) and match each of the financially distressed firms with a non-financially distressed (control) firm in the same industry, with similar total assets and in the same time-period (year). ${ }^{2}$ In this process, we lost additional firms for which suitable matching firms (11 firms) could not be identified and firms

\footnotetext{
${ }^{2}$ As in Peasnell et al. (2001), we used a cut-off of $+/-50 \%$ in the matching process. We tested, using a paired t-test, for differences in total assets of distressed and non-distressed firms. We find the two samples do not differ significantly suggesting that the matching process was successful.
} 


\section{Bank power, Governance and Distress}

with some missing data (6 firms). This reduced our sample to 184 financially distressed firms and non-financially distressed firms (i.e., 92 matched pairs) (hereafter distressed or non-distressed).

Our rationale for adopting a matched-pair design is that it provides a parsimonious means of controlling for potentially important confounding factors (see Hosmer and Lemeshow, 2000; Peasnell et al., 2001). In our case, because the study covers the period during, and following, the 2007-2009 financial crisis, the challenge would be to control for the impact of macroeconomic factors during this period, which adversely affected firms. By using the matched-pair research design, we can reasonably circumvent this problem - firms are matched based on the year, industry and size so that the confounding factors are the same. Further, the modelling approach we adoptconditional logistic regression (section 4.2 below), has the advantage of preserving the matched character of the sample (Hosmer and Lemeshow, 2000; Peasnell et al., 2001). To this extent, we can attribute some of the financial distress to governance structures.

\subsection{Empirical specification and variable definitions}

Following on from our matched-pair design, we employ a conditional logistic regression model. Our base model is depicted in Equation 1.

$$
\begin{aligned}
\text { FinDistress }_{t}= & \beta_{1} \text { Bank power }_{t-2}+\beta_{2} \text { Block ownership }_{t-2}+\beta_{3} \text { Board independence }_{t-2} \\
& +\beta_{x} \text { Block ownership }_{t-2} * \text { Bank power }_{t-2}+\beta_{y} \text { Board independence }_{t-2} * \text { Bank } \\
& \text { power }_{t-2}+\Sigma \beta_{z} \text { Control variables } t-2+\varepsilon
\end{aligned}
$$

The dependent variable, FinDistress, is financial distress likelihood measured as a dummy taking the value of 1 if a firm is classified as distressed, 0 otherwise (see section 4.1 above). In relation to the independent variables, Bank power captures the presence of a dual role bank in the firm. Spanish firms are required by the Real Decreto 1514/2007 (BOE, 2007) law to indicate in the annual report whether any shareholder owning at least $5 \%$ of shares is also a holder of debt claims in the firm. In defining bank power, we take the view that the bank does not have to be the largest blockholder to dominate decisions (see also Franks and Mayer, 1998, 2001). ${ }^{3}$

\footnotetext{
${ }^{3}$ We noted earlier, following Franks and Mayer (2001) and Tribo et al. (2010) that banks also derive their power from holding proxy votes. However, in defining bank power in the paper, we only considered whether the bank plays a dual role, that is, whether it is both lender and direct shareholder to the same firm. Data on proxy votes held by banks is not publicly available. To the extent that our bank power measure does not capture the proxy votes, this is a limitation of the paper.
} 


\section{Bank power, Governance and Distress}

Focusing on governance variables, Block ownership denotes measures that capture the power of all blockholders (other than the dual role bank itself), with at least 5\% ownership of the firm's shares. Following the literature, we take the view that both the level of block ownership and blockholder dispersion matter for monitoring (see Tribo et al., 2007; Konijn et al. 2011; Basu et al., 2016). Hence, our measure of block ownership includes three constructs: (i) total share of all blockholders (Total blocks), which is also split into pressure sensitive financial blockholders (PresSensit blocks), pressure resistant financial blockholders (PresResist blocks) and non-financial blockholders (Non-financial blocks) to capture the effects of blockholder type; (ii) the total ownership by the top three blocks (Top3 blocks) as well as the individual share of the first, second and third largest blockholder (Block 1, Block 2 and Block 3) and (iii) the dispersion of blockholders, measured in Number of blocks and Herfindahl index of equity stakes. We use the scaled Herfindahl index as in Konijn et al. (2011), calculated using the total ownership of the top three largest blockholders. ${ }^{4}$ Board independence captures the extent to which directors are independent and is proxied by CEO/Chair duality, Proprietary director chair and Outside directors. Outside directors are split into independent directors and proprietary directors.

Block ownership*Bank power and Board independence*Bank power are interaction terms, which we include to capture the effects of bank power given the firm's block ownership and board independence, respectively. We interpret a negative coefficient on the interaction term as indicating contests to bank power by the blockholders and boards and a positive coefficient as indicating weak monitoring or possibly coalitions between the bank and the mechanisms to reduce monitoring intensity. The sum of the coefficients of bank power $\left(\beta_{1}\right)$ and interaction terms (i.e., $\beta_{1}+\beta_{x} ; \beta_{1}+\beta_{y}$ ) captures the total effects of bank power when contests exist. If contests of bank power are strong (not strong) enough, we expect the total effects to be negative (positive). We test the significance of these effects using the Wald test (see Mangena et al., 2012).

Finally, we control for other variables that are motivated by prior studies. Managerial ownership is reported as positively related to financial distress (e.g., Abdullah, 2006; Fich and Slezak, 2008) and profitability, retained earnings and financial expense ratio are all shown to relate to financial distress (Opler and Titman, 1994; Pindado et al., 2008; Tinoco and Wilson, 2013; Manzaneque et al., 2016). All variables are defined in Table 1.

\footnotetext{
${ }^{4}$ The Herfindahl index $=\left[(\% \text { Block } 1)^{2}+(\% \text { Block } 2)^{2}+(\% \text { Block 3 })^{2}\right] /[(\%$ Block 1$)+(\%$ Block 2$)+(\%$ Block 3) $]($ see Konijn et al. $(2011)$. A higher number of blocks or lower Herfindahl index implies a high dispersion of blockholders in the firm.
} 


\section{Insert Table 1 about here}

A concern in our design relates to potential endogeneity problems inherent in most studies of this nature. In particular, the literature indicates board and ownership structure variables are often endogenously determined by performance (see Field and Sheehan, 2004). Thus, there are possibilities that the board and ownership variables and financial distress are jointly determined. In other words, firms may have changed their board and/or ownership structures in order to deal with their financial difficulty. For instance, banks have been shown to take up (more) equity stake when firms are in difficulty (James, 1995; Berlin et al., 1996). To reduce this problem, we lag our independent variables (e.g., Klasa, 2007; Dittmar and Mahrt-Smith, 2007). In this case, we collect our data for these variables at year $t_{t-2}$ relative to the financial distress year. The rationale for adopting a two-year-lag is to align with our measure of financial distress as developed using the approach in Pindado et al. (2008). In particular, since the criterion for the financial distress measure is that the firm must have been in decline for two consecutive years, we need to capture the effects of the variables prior to the first year of decline leading to financial distress (i.e., 2 years before this outcome). This helps to reduce the effects of changes, for example to bank power, block ownership or board independence, that may have been instituted at the first sign of decline.

\section{Empirical tests and results}

\subsection{Descriptive statistics}

In Table 2, we report the summary descriptive statistics for the sample. Panel A presents the statistics for distressed and non-distressed firms and examines whether they statistically differ in terms of bank power, measures of block ownership and board independence, and control variables. In Panel B, we compare whether firms with bank power differ with their counterparts. In both panels, we use the parametric $t$-test.

Insert Table 2 about here 


\section{Bank power, Governance and Distress}

Panel A shows that distressed firms are more likely than non-distressed firms to have a powerful bank (Bank Power). We observe that $44.7 \%$ and $22.4 \%$ of distressed and non-distressed firms, respectively, have bank power (significant at 1\%). Thus, at the univariate level, this is consistent with our hypothesis 1 . In relation to block ownership variables, the mean total ownership by all blockholders (Total blocks) between the two groups is not significantly different. As for type of block ownership, whilst distressed firms have greater ownership by pressure sensitive and pressure resistant blocks, the two groups have similar nonfinancial block ownership. The number of blockholders is different between the groups, but the Herfindahl index is not significant. In terms of the top three blockholders, only Block 3 differs. Overall, it appears that distressed firms have bank power presence and slightly greater block ownership than non-distressed firms.

For board independence, non-distressed firms are more likely to have CEO/Chair duality, but distressed firms are more likely to have proprietary director chair. Non-distressed firms have more Outside directors than distressed firms. When we split outside directors, we observe that non-distressed firms have more independent directors, while distressed firms have slightly more proprietary directors. Finally, managerial ownership in distressed firms is greater, and nondistressed firms have higher profitability and retained earnings, and lower financial expense ratio.

In Panel B, we observe that bank power firms are more likely to be distressed at $75 \%$ compared to $45.5 \%$ for non-bank power firms. No significant differences are detected between the two groups in respect of Total blocks, but bank power firms have greater ownership by pressure sensitive blocks whilst non-bank power firms appear to have slightly greater ownership by pressure resistant and nonfinancial blocks. Bank power firms have a larger number of blocks and greater ownership by the top three individual blocks and are more likely to have CEO/Chair or proprietary board chair. Non-bank power firms have more outside directors, independent directors and proprietary directors. Finally, non-bank power firms have higher profitability and retained earnings, but lower financial expense ratio than bank power firms.

\subsection{Variable correlations}

Table 3 presents the Pearson correlation matrix among the independent variables. 


\section{Bank power, Governance and Distress}

\section{Insert Table 3 about here}

The table shows that the correlations among the variables are generally low. In addition, we also inspected the variance inflation factors (VIF) (not tabulated) and found them to be low. As a rule of thumb, collinearity becomes a problem when the correlations and the VIFs exceed 0.90 and 10, respectively (see Greene, 2017). The highest correlations are between CEO/Chair and Proprietary director chair $(\mathrm{r}=-568)$ and independent and proprietary directors $(\mathrm{r}=-0.453)$. These magnitudes are well below the benchmarks, indicating no concerns about potential multicollinearity problems.

\subsection{Results of conditional logistic regression analyses}

We now turn to exploring the effects of bank power on financial distress likelihood and the monitoring role of block ownership and board independence. We start by testing whether our financial distress likelihood measure is related to financial factors as in prior financial distress prediction models (see Opler and Titman, 1994; Pindado et al., 2008; Hernandez-Tinoco and Wilson, 2013). Our results (not tabulated here) are consistent with the literature, and in the correct direction - profitability and retained earnings are negative, and financial expense ratio is positive. This gives us reasonable confidence that our financial distress measure is valid. In the following sections, we analyse the results of testing our hypotheses as observed in Table 4.

\subsubsection{Bank power and financial distress-Hypothesis 1}

In this section, we explore the effects of bank power on the likelihood of financial distress. We start by running a reduced form of Equation 1 that excludes interaction terms as in most prior similar studies. The results are reported in Table 4.

\section{Insert Table 4 about here}

In column 1 of Table 4, we estimate the effects of block equity ownership by banks (Bank blocks) on financial distress consistent with some prior studies examining the effects of bank power on 


\section{Bank power, Governance and Distress}

firm outcomes (e.g., Lin et al., 2009; Luo et al., 2011; Pan and Tian, 2015). The results show that although the coefficient of bank ownership is positive, it is not significant. ${ }^{5}$ This suggests that while bank ownership may lower performance as in these prior studies, this may not translate into financial distress. However, these results may be because share ownership alone may only be capturing one dimension of bank power - equity holding, but not debt holding.

In this paper, our position is that bank power derives from holding both equity and debt rather than just an equity stake, and it is that power that may have effects on the likelihood of financial distress - our hypothesis 1 . Columns 2 to 8 of Table 4 present the regression results of testing this hypothesis using a dummy variable to capture bank power. In column 2, we report the estimates with Total blocks and outside directors to test whether the level of total block ownership and the total outside directors matter for financial distress. The model in column 3 is a variant of that in column 2, but splits Total blocks into pressure sensitive blocks, pressure resistant blocks and non-financial blocks, and outside directors into proprietary and independent directors. This split is aimed to help understanding of whether the type of blockholder and type of outside director has implications for financial distress. This is supported by the rationale that prior studies suggest blockholders have different monitoring incentives (Thomsen et al., 2006; Cornett et al., 2007). We report in columns 4 and 5, the estimates for the models that include, respectively, the combined total of the top three block ownership (Top3 blocks) and each of the individual top three blockholders (i.e., Block 1, Block 2 and Block 3). These estimates help to capture not only the effects of the total size of ownership by the top largest blockholders, but potentially also the effects of their type (Basu et al., 2017). This approach is supported by the multiple blockholder literature that suggests that additional blockholders contest rent extraction by the controlling power (see Maury and Pajuste, 2005; Basu et al., 2016, 2017). Models in columns 6 and 7 capture the impact of blockholder dispersion as measured in the number of blockholders and Herfindahl index, respectively - the literature suggests that these matter for monitoring (see Tribo et al., 2007; Konijn et al., 2011; Basu et al., 2016). Finally, in column 8, we split proprietary directors into types based on appointing blockholders-(i) pressure resistant blocks (PropResist directors), (ii)

\footnotetext{
${ }^{5}$ It is a possibility that it is the presence of bank ownership rather than ownership itself. This is particularly so given that banks sometimes are holders of proxy votes which may increase their voting power. Therefore, we rerun the model replacing bank ownership with a dummy variable measured as 1 if a bank is a blockholder, and 0 , otherwise. The results remain positive and insignificant.
} 


\section{Bank power, Governance and Distress}

pressure sensitive blocks (PropSensist directors) and (iii) non-financial blocks (PropNon-fin directors). Our rationale is to understand whether their monitoring effectiveness differ.

All the model configurations are significant in explaining financial distress as indicated by model $\chi^{2}$ statistics (significant at $5 \%$ ) and all the coefficients are consistently stable throughout. In spite of the model specification, the coefficients of Bank power are positive and significant at $1 \%$ level. This provides support for Hypothesis 1 . These results are consistent with the literature on bank dual holding and firm value (e.g., Lin et al., 2009; Luo et al., 2011; Pan and Tian, 2015) and support the notion that firms in which banks have power are more likely to enter financial distress. They also support theories proffered by Rajan (1992), Petersen and Rajan (1994) and Berlin et al. (1996), among others, where-in banks are argued to extract rents from borrower firms. This implies that bank power may be detrimental to firm survival. One way by which the bank can influence decisions is via its proprietary directors. We therefore rerun the models replacing bank power dummy with the proportion of the dual bank proprietary directors, but the results are insignificant in all specifications. We thus do not explore this issue any further.

With respect to the block ownership and board independence variables, we find that except for Block 1 and Block 2 (column 5) and block dispersion as measured in number of blocks (column 6) and Herfindahl index (column 7), all other variables are not significant. ${ }^{6}$ The results for Blocks 1 and 2, number of blocks and Herfindahl index are significant at 5\%. These results are consistent with the multiple blockholder literature that documents that additional blockholders monitor and countervailing the effects of the controlling power (e.g., Pajuste and Maury, 2005; Attig et al., 2008; Crespi and Renneboog, 2010; Basu et al., 2016). They are also consistent with studies suggesting that high blockholder dispersion weakens the ability of blockholder monitoring (Tribo et al., 2007; Konijn et al., 2011; Basu et al., 2017).

\subsubsection{Bank power, block ownership and board independence}

Thus far, our results as reported in Table 4 are consistent with the notion that banks use their power to extract rents. However, similar to most prior studies examining the effects of banks on firm outcomes (e.g., Morck et al., 2000; Lin et al., 2009; Luo et al., 2011; Pan and Tian, 2015), our

\footnotetext{
${ }^{6}$ Our non-financial blocks combine individual and corporate blocks. However, Basu et al. (2017) notes that individual blocks have opposite effects on monitoring. Consequently, we split the non-financial blocks into individual blocks and corporate blocks. Both are not significant and are in same direction as the total non-financial blocks. We therefore do not pursue this distinction any further.
} 


\section{Bank power, Governance and Distress}

analyses do not capture the monitoring of bank actions by blockholders and boards of directors. As we argued in Section 3, the ability of the bank to extract rents is dependent upon monitoring by blockholders and boards. Put another way, the bank power effects on the likelihood of financial distress are moderated by block ownership and board structures. We address this by running the regression including interaction terms (full Equation 1). We first centre all the continuous block ownership and board independence variables and run the regressions with centred variables as recommended in Aiken and West (1991) to reduce the effects of multicollinearity inherent in interaction models. Our inspection of the VIFs shows that they are all below the 10 thresholds. The results are presented in Table 5. Our results on bank power are maintained across all specifications. We discuss the results of the interactions in the following subsections.

\section{Insert Table 5 about here}

\subsubsection{The role of block ownership-Hypothesis 2}

While bank power is associated with the likelihood of financial distress, thus supporting Hypothesis 1, it is premature to suggest that bank power precipitates financial distress. We argued in Hypothesis 2 that the extent to which bank power harms the firm depends upon the contests by blockholders. If the contests are strong, we would expect the likelihood of financial distress due to bank power to be lower, and if they are weak, then financial distress due to bank power is magnified. In our models, these effects are captured by the interaction terms.

We start the analyses of the results in Table 5 by examining the effects of measures of blockholder power based on the level of block equity ownership (Total blocks, PresSensit blocks, PresResist blocks, Non-financial blocks, Top3 blocks and Block 1, Block 2, Block 3). These are all

similar to Table 4. However, when we examine the interaction terms, the results show that Total blocks*Bank power (columns 1, 5-7), PresResist blocks*Bank power (column 2) and Block 1 *Bank power (column 4) are significant. PresSensit blocks*Bank power and Non-financial blocks*Bank power (columns 2), Top3 blocks*Bank power (column 3) and Block 2*Bank power and Block $3 *$ Bank power (column 4) are not significant although negative. These findings suggest that the contests of bank power by blockholders are primarily driven by pressure resistant blockholders who also appear to be the first largest blockholder (Block 1). This is consistent with the literature 


\section{Bank power, Governance and Distress}

that argues that pressure sensitive blocks and non-financial blocks are subject to agency problems, for example, due to their business relationships with the firm (Cornett et al., 2007; Bhattacharya and Graham, 2009) or just passive monitors of the bank power actions.

In relation to blockholder dispersion, the coefficient of the interaction term is positive and significant for the Number of blocks*Bank power while it is negative and significant for the Herfindahl index*Bank power (columns 5 and 6 respectively). This implies that for firms with high blockholder dispersion, contests by blockholders to bank power actions are weakened with implications for financial distress (see Tribo et al., 2007; Konijn et al., 2011).

The preceding results are consistent with blockholders using their power to contest bank actions and reducing financial distress. However, they do not tell us whether these contests are strong enough to eliminate financial distress due to bank power actions. We explore this by examining the sum of the coefficients of bank power and the interaction terms, which are reported in Panel B of Table 5. The total of bank power and the interaction term for total block ownership (Total Blocks*Bank power, $\beta_{1}+\beta_{20}$ ), pressure resistant blocks (PresResist blocks*Bank power, $\beta_{1}+\beta_{22}$ ) and first largest blockholder (Block $1 *$ Bank power, $\beta_{1}+\beta_{27}$ ) are significant at $10 \%$ level. This suggests that contests by blockholders are strong enough to off-set the bank power effects on financial distress. For blockholder dispersion, the total effects are positive and significant for Number of blocks*Bank power $\left(\beta_{1}+\beta_{24}\right)$ and Herfindahl index*Bank power $\left(\beta_{1}+\beta_{25}\right)$. This is in line with the multiple blockholders literature (see Maury and Pajuste, 2005; Tribo et al., 2007; Basu et al., 2016). Taking all this together, our findings provide support for Hypothesis 2.

\subsubsection{The role of board independence-Hypothesis 3}

In our third hypothesis (H3), we posited that bank power effects on financial distress depend on the independence of the board. Thus, strong board independence would reduce financial distress due to bank power actions. As earlier noted, our proxies for board independence are CEO/Chair duality, Proprietary director chair and Outside directors.

With respect to $\mathrm{CEO} /$ Chair duality, we find that the interaction term, CEO/Chair duality*bank power, is positive, and not significant. As for proprietary chair director, Proprietary director chair*bank power is positive and highly significant. Both the sum of the coefficients of bank power and CEO/Chair duality*bank power $\left(\beta_{1}+\beta_{30}\right)$ and Proprietary director chair*bank power $\left(\beta_{1}+\beta_{31}\right)$ are also positive and significant. These results suggest that the effects of bank 


\section{Bank power, Governance and Distress}

power are significantly higher for firms in which the position of chair is held by the CEO or proprietary director. In other words, financial distress due to bank power is more likely in firms with a CEO/chair or proprietary board chair. This suggests that banks may influence decisions in their favour via the CEO/Chair or proprietary director chair as appropriate. This is supported by Franks and Mayer (1998) who, in the context Germany, show that powerful banks were able to influence decisions via (their) supervisory board chairs. Similarly, examining Chinese firms, Luo et al. (2011) document evidence suggesting that banks facilitate better perks for the CEO to motivate them to implement strategies that benefit the bank. The reality is that not all CEO/Chairs or proprietary director board chairs are prone to bank influence. Hence, we explore our dataset to provide insights into the identities of the board chairs in order to understand whose interests they may be serving (We can only do this for proprietary director chairs as it is difficult to determine who the $\mathrm{CEO} /$ chair is aligned to). In our dataset, we have 44 proprietary board chairs, of which five (5) are aligned to pressure resistant blockholders and 39 to non-financial blocks (7 are corporate blocks and 32 are individual blocks) — none representing the powerful bank (or any other banks). Non-financial blocks are often characterised as associates with incentives for private benefits (Thomsen et al., 2006; Cornett et al., 2007) and their appointed proprietary director chairs may be driving our results. We rerun the models by replacing the original proprietary chair dummy (based on 44 proprietary chairs) with a dummy based on the 39 non-financial blocks proprietary director chairs. The results (not tabulated here) remain. It therefore appears that the powerful banks may find it easier to form a coalition with these chairs to drive board decisions in their favour. It is possible that these proprietary director chairs suffer from conflicts of interests due to business ties that their principal blocks may have with the firm (Thomsen et al., 2006; Cornett et al., 2007; Tribo et al., 2007) and that such ties rely on the influence of the powerful bank to materialise.

In relation to outside directors, the results in columns 1,5 and 6 show that the coefficient of the interaction term, Outside directors*Bank power is negative and significant at the $10 \%$ level suggesting some level of contests to bank power. The sum of the coefficients, $\beta_{1}+\beta_{32}$, is negative, but not significant. This indicates that contests by outside directors is enough to off-set financial distress due to bank power. To understand where this contest derives from, we rerun the regressions by splitting outside directors into independent directors and proprietary directors (columns 2, 3 and 4). We also split proprietary directors into those representing (i) pressure resistant blocks (PropResist directors), (ii) pressure sensitive blocks (PropSensist directors) and 


\section{Bank power, Governance and Distress}

(iii) non-financial blocks (PropNon-fin directors (column 7). We observe that the coefficients of independent directors $*$ bank power and proprietary directors ${ }^{*}$ bank power are both negative, but only proprietary directors $*$ bank power is significant at $5 \%$. The sum of the coefficients, $\beta_{1+} \beta_{34}$, is negative and significant at $10 \%$. These results suggest that the contests by outside directors are primarily due to proprietary directors. These findings are consistent with other studies that show the importance of proprietary directors in monitoring (e.g., Pucheta-Martinez and Garcia-Meca, 2014; Manzaneque et al., 2016; Fuente et al., 2017). In column 7, we show that the coefficient of PropResist directors*Bank power, is negative and significant, but those of PropSensist directors and PropNon-fin directors, though negative, are insignificant. The results on PropNon-fin directors may be due to proprietary director chairs. Hence, we recalculate our measure eliminating proprietary director chairs and whilst the coefficient improves, it is still insignificant. Nevertheless, we suggest that proprietary directors contest bank actions and that such contests are likely to come, in the main, from those appointed by pressure resistant blockholders.

\subsection{Robustness checks}

The results in Tables 4 and 5 are consistent with the notion that bank power increases the likelihood of financial distress. However, it is possible that there are alternative explanations for these results. In this section, we run additional analyses to check the robustness of our results. First, prior work documents that banks take up equity stakes when firms are in financial difficulties (e.g., Gilson, 1990; James, 1995; Berlin et al., 1996) and that the costs of financial distress are lower for firms in which banks are both lender and equity holder (e.g., Hoshi et al., 1990). Thus, having bank power in the firm might not be random - that is, firms that are likely to enter financial distress might have incentives to have the bank take up both debt and equity. Hence, our tests potentially suffer from a selection bias (Heckman, 1979, Chung et al., 2015). Although, we have two-year lagged our independent variables to reduce this endogeneity concern, lagging variables may not be enough (e.g., Bellemare et al., 2015). We address this concern by estimating a two-staged Heckman 1979 model in similar fashion to Chung et al. (2015). In the first stage, we estimate the following probit model which models the decision to hold both equity and debt in the same firm.

$$
\begin{aligned}
\text { Bank power }_{t} & =\beta_{0}+\beta_{1} \text { Log total asset }_{t-2}+\beta_{2} \text { PresSensit blocks }_{t-2}+\beta_{3} \text { PreResist blocks }_{t-2} \\
& +\beta_{4} \text { Nonfinancial blocks }_{t-2}+\beta_{5} \text { CEO/Chair }_{t-2}+\beta_{6} \text { Outside directors }_{t-2}
\end{aligned}
$$


$+\beta_{7}$ Managerial ownership on $2+\beta_{8}$ Financial expense $_{t-2}+\beta_{9}$ Profitability $_{t-2}$

$+\beta_{10}$ Retained earnings $s_{t-3}+\beta_{11}$ Industry controls $+\varepsilon$

All variables are as defined in Table 1. The model is based on the findings of prior studies. James (1995) show that banks hold shares in large firms (Log total assets) and high leverage firms (financial expense ratio). Bank ownership has been found to be related to performance (profitability; retained earnings) and inside ownership (managerial ownership) (Limpaphayom and Polwitoon, 2004; Barucci and Mattesini, 2008; Lin et al., 2009). We also add block ownership variables and outside directors as governance structures have implications for the firm's capital structure (Granado-Peiro and Lopez-Gracia, 2017). In the second stage, we use the estimates from Equation 2 to compute the inverse Mills ratio (InvMills) (as in Heckman, 1979), which we introduce in Equation 1 as an additional variable. The results are reported in Table 6 and are similar to those reported in Tables 4 and 5.

\section{Insert Table 6 about here}

Second, the financial distress metric we employed in our analyses is an ex-ante measure based on Pindado et al. (2008). Although this ex-ante measure is considered reliable because it captures both accounting and market variables (see Hernandez-Tinoco and Wilson, 2013), the results may be driven by the measure used. We therefore perform robustness checks using an alternative measure of financial distress. Specifically, we employ a measure of financial distress based on the Altman's Z-Score model, an approach used in other previous studies to perform robustness checks (see Pindado et al., 2008; Hernandez-Tinoco and Wilson, 2013). We use the model as modified by Lizarraga-Dallo (1998) for the Spanish market. This model classifies 79 (42.9\%) of our sample firms as distressed and $105(57.1 \%)$ as non-distressed. We then run a logit model which includes all variables in Equation 1 as well as additional control variables in log of total assets, industry and year dummies. The results are reported in Table 7.

Insert Table 7 about here 


\section{Bank power, Governance and Distress}

Reassuringly, the results are similar to those obtained using the measure of financial distress based on Pindado et al. (2008). The exceptions are: the number of blocks and Herfindahl index change to $1 \%$ significance level, PresSensit blocks*Bank power is now significant at $10 \%$; and managerial ownership is not significant. Nevertheless, the direction of the coefficients remains unaltered.

Finally, we also run further additional tests for which the results are not tabulated here. It is possible that smaller firms, being riskier can only borrow from banks while larger firms have other sources of external funding. Hence, our findings may be driven by this size effect. Whilst this problem is somewhat dealt with via our matched sample design and the conditional regression approach, we undertake tests to provide confidence that this effect does not influence our results. We create a dummy variable firm size by dividing our sample into small and large firms via the median total assets (and also market capitalisation) and run t-tests comparing the ratio of bank debt to total debt of the two groups of firms. We find no significant differences suggesting that the size effect is not an issue. We also introduce additional variables in board size, audit committee size, board meetings and the proportion of female directors and our results remain largely similar. To the extent that our results are not qualitatively different in all these checks, we are reasonably confident that our results are robust.

\section{Concluding remarks}

We examine the effects of bank power (proxied by the holding of both debt and equity in the same firm) on the likelihood of financial distress in Spanish listed firms. We suggested following most recent literature that banks may deploy their power to extract rents from the firm, leading to financial distress. However, we also draw from the literature on multiple blockholders and board structure and argue that the ability of the bank to extract rents and push the firm into financial distress is contested by blockholder power and the board. Thus, rent extraction cannot persist to harm the firm. Using a matched sample of distressed and non-distressed firms and applying a conditional logistic regression model, we obtain results that are consistent with our hypotheses. These results are robust to endogeneity and other additional sensitivity tests.

We find that bank power is positively related to the likelihood financial distress. This implies that holding other effects constant, banks holding both equity stakes and debt may be detrimental to the firm. This is consistent with the conflict of interest between debt- and equity-holders. 


\section{Bank power, Governance and Distress}

However, bank power actions are contested in firms with higher block ownership and greater board independence. In relation to block ownership, the contests are primarily due to pressure resistant blockholders, and these are likely to be the largest blockholder in the firm. With respect to board independence, the presence of a proprietary director chair of the board magnifies the bank power effects on financial distress. Outside directors reduce the effects of bank power, but these are primarily due to proprietary directors. These results are consistent with the notion that bank power actions may harm the firm, but block ownership and boards contest value destroying actions.

Our paper contributes to ongoing research that focuses on the effects of equity ownership by banks as well as to the corporate governance literature in general. The findings also provide useful guidance to policy makers about governance structures that enhance protection of stakeholders. For example, regulators could consider strengthening the law that limits the banks' legal rights in the event of failures when they are both equity and debtholder in the firm. They are also useful to investors' understanding of settings under which expropriation is more likely. Thus, they inform investors about conditions where powerful actors may be detrimental to the firm.

As with all studies, our findings and the related contributions must be understood in the context of some limitations. First, our sample focused only on the Spanish environment, thus limiting generalisability of the findings. Whilst the Spanish setting makes interesting analysis, future research could build on our study by extending the analysis to an international setting. Second, we limited our focus on understanding financial distress likelihood. Future work could extend by examining whether firms went into bankruptcy and understand the role of the powerful banks in this context. Related to this, future research could examine other organisational outcomes, for example, performance. Third, our sample is rather small, thus affecting the power of our tests. However, small samples are not unusual in studies of this nature (see Peasnell et al., 2001). Despite these limitations, our work contributes to the literature and has policy and practical implications.

\section{References}

Abdullah, S.N. (2006). Board structure and ownership in Malaysia: the case of distressed listed companies, Corporate Governance, 6(5): 582-594.

Abdullah, N. A. H., Ma'aji, M. M., \& Khaw, K. L. H. (2016). The value of governance variables in predicting financial distress among small and medium-sized enterprises in Malaysia. Asian Academy of Management Journal of Accounting \& Finance, 12.

Aebi, V., Sabato, G. \& Schmid, M. (2012). Risk management, corporate governance, and bank performance in the financial crisis, Journal of Banking \& Finance, 36(12): 3213-3226. 


\section{Bank power, Governance and Distress}

Agrawal, R. and Elston, J.A. (2001). Bank-firm relationships, financing and firm performance in Germany, Economics Letters, 72 (2): 225-232.

Aiken, L.S. \& West, S.G. (1991). Multiple regression: Testing and interpreting interactions, London: Sage Publications.

Anderson, C.A. \& Anthony, R.N. (1986). The new corporate directors. New York: John Wiley.

Anderson, R.C. \& Reeb, D.M. (2003). Founding-family ownership and firm performance: Evidence from the S\&P 500. The Journal of Finance, LVIII (3): 1301-1328.

Attig, N., Guedhami, O., \& Mishra, D. (2008). Multiple large shareholders, control contests, and implied cost of equity. Journal of Corporate Finance, 14(5), 721-737.

Azofra-Palenzuela, V., López-Iturriaga, F.J. \& Tejerina-Gaite, F. (2007). Banks as shareholders: the Spanish model of corporate governance. In Columbus, F.J. (Eds), Corporate Governance: Issues and Challenges, Nova Science Publishers.

Bach, S.B. \& Smith, A.D. (2007). Are powerful CEOs beneficial to post-IPO survival in high technology industries: An empirical investigation, Journal of High Technology Management Research, 18: 31-42.

Barucci, E. \& Mattesini, F. (2008). Bank shareholding and lending: complementarity or substitution? Some evidence from a panel of large Italian firms, Journal of Banking \& Finance, 32: 2237-2247.

Basu, N., Paeglis, I. \& Rahnamaei, M. (2016). Multiple blockholders, power and firm value, Journal of Banking \& Finance, 66: 66-78.

Basu, N., Paeglis, I. \& Toffanin, M. (2017). Reading between the blocks, Journal of Corporate Finance, 45: 294-317.

Bebchuk, L.A., Kraakman, R. \& Triantis, G. (2000). Stock pyramids, cross-ownership and dual class equity, In R. Morck (ed), Concentrated Corporate Ownership. Chicago: University of Chicago Press.

Bellemare, M. F., Masaki, T. \& Pepinsky, T.B. (2015). Lagged explanatory variables and the estimation of causal effects. http://mpra.ub.uni-muenchen.de/62350/(6 February 2017).

Bennedsen, M. \& Wolfenzon, D. (2000). The balance of power in closely held corporations, Journal of Financial Economics, 58: 113-139.

Berlin, M., John, K. \& Saunders, A. (1996). Bank equity stakes in borrowing firms and financial distress, Review of Financial Studies, 9(3): 889-919.

Bertrand, M., Mehta, P. \& Mullainathan, S. (2002). Ferreting Out Tunneling: An Application to Indian Business Groups, The Quarterly Journal of Economics, 117:121-48.

Bhattacharya, P. S. \& Graham, M. (2007). Institutional Ownership and Firm Performance: Evidence from Finland, Available at SSRN: https://ssrn.com/abstract=1000092 (accessed 27 October 2019).

Black, B. \& Kim, W. (2012). The effect of board structure on firm value: A multiple identification strategies approach using Korean data, Journal of Financial Economics, 104: 203-226.

BOE (Official State Bulletin) (2003). Law 22/2003, Spanish Insolvency Act 22-2003. 164, 10 July. BOE (Official State Bulletin) (2007). Plan General de Contabilidad. Real Decreto 1514/2007 law, 278, 16 November.

Bolton, P. \& Von Thadden, E. (1998). Blocks, liquidity and corporate control, Journal of Finance, 53 (1): 1-25.

Brickley, J.A., Coles, J.L. \& Jarrell, G. (1997). Leadership structure: separating the CEO and chairman of the board, Journal of Corporate Finance, 3: 189-220. 


\section{Bank power, Governance and Distress}

Burkart, M., Gromb, D. \& Panunzi, F. (1997). Large shareholders, monitoring and the value of the firm, The Quarterly Journal of Economics, 112: 693-728.

Capital Companies Law, (2010). Royal Legislative Decree 1/2010, of July 2, approving the consolidated text of the Capital Companies Law.

Chung, H., Judge, W. Q. \& Li, Y. H. (2015). Voluntary disclosure, excess executive compensation, and firm value, Journal of Corporate Finance, 32: 64-90.

Comisión Nacional del Mercado de Valores (CNMV, 2018). Corporate Governance Reports of Issuers of Securities Admitted to Trading on Regulated Markets. Retrieved from https://www.cnmv.es/DocPortal/Publicaciones/Informes/IAGC_2012_ENen.pdf. Accessed on 5 May 2020.

Cornett, M.M., Marcus, A.J., Saunders, A. \& Tehranian, H. (2007). The impact of institutional ownership on corporate operating performance, Journal of Banking \& Finance, 31(6): 17711794.

Cremers, K. J. \& Nair, V. B. (2005). Governance mechanisms and equity prices, Journal of Finance, 60(6): 2859-2894.

Crespi, R. \& Renneboog, L. (2010). Is (Institutional) shareholder activism new? Evidence from UK shareholder coalitions in the pre-Cadbury era, Corporate Governance: An International Review, 1894): 274-295.

Crespi-Cladera, R. \& Garcia-Cestona, M. A. (2002). Ownership and Control of the Spanish listed firms, In F. Barca and M. Becht (eds), The Control of Corporate Europe, London: Oxford University Press.

Degryse, H. \& Van Cayseele, P. (2000). Relationship lending within a bank-based system: Evidence from European small business data, Journal of Financial Intermediation, 9: 90-109.

Diamond, D. (1984). Financial intermediation and delegated monitoring, Review of Economic Studies, 51: 393-414.

Diamond, D. (1991). Monitoring reputation: The choice between bank loans and publicly placed debt, Journal of Political Economy, 99: 689-721.

Dittmar, A. \& Mahrt-Smith, J. (2007). Corporate governance and the value of cash holdings. Journal of Financial Economics, 83(3): 599-634.

Donker, H., Santen, B. \& Zahir, S. (2009). Ownership structure and the likelihood of financial distress in the Netherlands, Applied Financial Economics, 19(21): 1687-1696.

Dowell, G.W., Shackell, M. \& Stuart, N. (2011). Boards, CEOs, and surviving a financial crisis: Evidence from the internet shakeout, Strategic Management Journal, 32(10): 1025-1045.

Elloumi, F. \& P.J. Gueyle, P.J. (2001). Financial distress and corporate governance: an empirical analysis, Corporate Governance, 1(1): 15-23.

Erkens, D.H., Hung, M. \& Matos, P. (2012). Corporate governance in the 2007-2008 financial crisis: Evidence from financial institutions worldwide, Journal of Corporate Finance, 18: 389-411.

Fama, E. \& Jensen, M. (1983). Separation of Ownership and Control, Journal of Law and Economics, 26(2): 301-325.

Fich, E. \& Slezak, S. (2008). Can Corporate Governance Save Distressed Firms from Bankruptcy? An Empirical Analysis? Review of Quantitative Finance and Accounting, 30(2): 225-251.

Field, L. C. \& Sheehan, D.P. (2004). IPO Underpricing and Outside Blockholdings, Journal of Corporate Finance, 10: 263-280.

Franks, J. \& Mayer, C. (2001). Ownership and control of German corporations, Review of Financial Studies, 14 (4): 943-977. 
Franks, J. \& Mayer, C. (1998). Bank control, takeovers and corporate governance in Germany, Journal of Banking \& Finance, 22: 1385-1403.

Fuente, J.A., Garcia-Sanchez, I.M. \& Lozano, M.B. (2017). The role of the board of directors in the adoption of GRI guidelines for disclosure of CSR information, Journal of Cleaner Production, 141(10): 737-750.

García Osma, B. \& Gill-de-Albornoz Noguer, B. (2007). The effect of the board composition and its monitoring committees on earnings management: evidence from Spain, Corporate Governance: An International Review, 15(6): 1413-1428.

García-Posada, M. \& Mora-Sanguinetti, J.S. (2014). Are there alternatives to bankruptcy? A study of small business distress in Spain, SERIEs, 5: 287-332

Garcia-Sanchez, I. M., Cuadrado-Ballesteros, B., \& Sepulveda, C. (2014). Does media pressure moderate CSR disclosures by external directors?, Management Decision.

Gilson, S. C. (1990). Bankruptcy, boards, banks, and blockholders: Evidence on changes in corporate ownership and control when firms default, Journal of financial economics, 27(2), 355-387.

Granado-Peiro, N. \& Lopez-Gracia, J. (2017). Corporate governance and capital structure: A Spanish study, European Management Review, 14: 33-45.

Greene, W.H. (2017). Econometric Analysis. New York: Pearson.

Heckman, J. J. (1979). Statistical models for discrete panel data. Chicago: Department of Economics and Graduate School of Business, University of Chicago.

Hernandez-Tinoco, M. \& Wilson, N. (2013). Financial distress and bankruptcy prediction among listed companies using accounting, market and macroeconomic variables, International Review of Financial Analysis, 30: 394-419.

Hoshi, T., Kashyap, A. \& Scharfstein, D. (1990). The role of banks in reducing the costs of financial distress in Japan, Journal of Financial Economics, 27(1): 67-88.

Hoskisson, R. E., Hitt, M. A., Johnson, R. A., \& Grossman, W. (2002). Conflicting voices: The effects of institutional ownership heterogeneity and internal governance on corporate innovation strategies. Academy of Management journal, 45(4), 697-716.

Hosmer, D.W. \& Lemeshow, S. (2000). Applied Logistic Regression. New York: John Wiley.

Hower, D. (2016). The role of bank relationships when firms are financially distressed, Journal of Banking \& Finance, 65: 59-75.

International Monetary Fund. (2012). World Economic Outlook. Growth Resuming, Dangers Remain, Washington: IMF.

Ivashina, V., Nair, V.B., Saunders, A., Massoud, N. \& Stover, R. (2009). Bank debt and corporate governance, Review of Financial Studies, 22(1): 41-77.

James, C. (1995). When do banks take equity in debt restructurings?, Review of Financial Studies, 8(4): 1209-1234.

Jensen, M.C. (1993). The modern industrial revolution, exit, and the failure of internal control systems, Journal of Finance, 48(3): 831-880.

John J. \& Kedia, S. (2006). Design of Corporate Governance: Role of Ownership Structure, Takeovers, and Bank Debt, NYU Working Paper No. CLB-06-023, Available at SSRN: https://ssrn.com/abstract=1291611 (Accessed 27 October, 2019).

Kang, J. \& Shivdasani, A. (1997). Corporate restructuring during performance declines in Japan, Journal of Financial Economics, 46: 29-65. 


\section{Bank power, Governance and Distress}

Kashyap, A.K., Rajan, R.G. \& Stein J. (2008). Rethinking capital regulation, 2008 Economic Symposium-Maintaining Stability in a Changing Financial System, Federal Reserve Bank of Kansas City.

Kawai, M., Hashimoto, J. \& Izumida, S. (1996). Japanese firms in financial distress and main banks: Analyses of interest-rate premia. Japan and the World Economy, 8(2), 175-194.

Klasa, S. (2007). Why do controlling families of public firms sell their remaining ownership stake?, Journal of Financial and Quantitative Analysis, 42(2): 339-367.

Konijn, S. J., Kräussl, R., \& Lucas, A. (2011). Blockholder dispersion and firm value. Journal of Corporate Finance, 17(5), 1330-1339.

Kroszner, R.S. \& Strahan, P.E. (2001). Bankers on boards: monitoring, conflicts of interest, and lender liability, Journal of Financial Economics, 62(3): 415-452.

Leech, D., \& Manjón, M. C. (2002). Corporate governance in Spain (with an application of the power indices approach). European Journal of Law and Economics, 13(2), 157-173.

Limpaphayom, P. \& Polwitoon, S. (2004). Bank relationship and firm performance: evidence from Thailand before the Asian financial crisis, Journal of Business Finance and Accounting, 31 (9): 306-368.

Lin, X., Zhang, Y. \& Zhu, N. (2009). Does bank ownership increase firm value? Evidence from China, Journal of International Money and Finance, 28(4): 720-737.

Lizarraga-Dallo, F. (1998). Bankruptcy prediction models: Does Altman's 1968 model work among Spanish firms? Revista de Contabilidad, 1(1): 137-164.

Luo, W., Zhang, Y. \& Zhu, N. (2011). Bank ownership and executive perquisites: New evidence from an emerging market, Journal of Corporate Finance, 17: 352-370.

Mahrt-Smith, J. (2006). Should banks own equity stakes in their borrowers? A contractual solution to hold-up problems, Journal of Banking \& Finance, 30(10): 2911-2929.

Mangena, M., Tauringana, V. \& Chamisa, E. (2012). Corporate boards, ownership structure and firm performance in an environment of severe political and economic crisis, British Journal of Management, 23(1): 23-41.

Manzaneque, M., Merino, E. \& Priego, A.M. (2016). The role of institutional shareholders as owners and directors and financial distress likelihood-evidence from a concentrated ownership context, European Management Journal, 34(4): 439-451.

Maury, B. \& Pajuste, A. (2005). Multiple large shareholders and firm value, Journal of Banking \& Finance, 29(7): 1813-1834.

Morck, R., Nakamura, M. \& Shivdasani, A. (2000). Banks, Ownership Structure, and Firm Value in Japan, The Journal of Business, 73(4): 539-567.

Opler, T.C. \& Titman, S. (1994). Financial Distress and Corporate Performance, Journal of Finance, 49(3): 1015-1040.

Pagano, M. \& Roell, A. (1998). The choice of stock ownership structure: agency costs, monitoring, and the decision to go public, Quarterly Journal of Economics, 113(1): 187-225.

Pan, X. \& Tian, G.G. (2015). Does banks' dual holding affect bank lending and firms' investment decisions? Evidence from China, Journal of Banking \& Finance, 55: 406-424.

Peasnell, K., Pope, P. \& Young, S. (2001). The characteristics of firms subject to adverse ruling by the Financial Reporting Review Panel, Accounting and Business Research, 31(4): 291-311.

Peek, J. \& Rosengren, E.S. (2005). Unnatural selection: Perverse incentives and the misallocation of credit in Japan, American Economic Review, 95 (4): 1144-1166.

Petersen, M.A. \& Rajan, R. (1994). The benefits of lending relationships: Evidence from small business data, Journal of Finance, 49: 3-37. 


\section{Bank power, Governance and Distress}

Pindado, J., Rodriguez, L. \& De la Torre, C. (2008). Estimating Financial Distress Likelihood, Journal of Business Research, 61(9): 995-1003.

Pinkowitz, L. \& Williamson, R. (2001). Bank power and cash holdings: Evidence from Japan, Review of Financial Studies, 14(4): 1059-1082.

Pucheta-Martínez, M. C., \& García-Meca, E. (2014). Institutional investors on boards and audit committees and their effects on financial reporting quality, Corporate Governance: An International Review, 22(4): 347-363.

Rajan, R. G. (1992). Insiders and outsiders: The choice between relationship and arm's length debt, Journal of Finance, 47: 1367-1400.

Ruiz-Mallorquí, M. \& Santana-Martín, D.J. (2009). Ultimate institutional owner and takeover defenses in the controlling versus minority shareholders context, Corporate Governance: An International Review, 17(2): 238-254.

Schenone, C. (2009). Lending relationships and information rents: Do banks exploit their information advantages, Review of Financial Studies, 23 (3): 1149-1199.

Shleifer, A. \& Vishny, R. (1997). A survey of corporate governance, Journal of Finance, 52 (2): 737-783.

Stein, J.C. (1989). Efficient capital markets, inefficient firms: a model of myopic corporate behavior, Quarterly Journal of Economics, 104: 655-669.

Taylor, J. (2009). The financial crisis and the policy responses: an empirical analysis of what went wrong, Critical Review: A Journal of Politics and Society, 21 (2-3): 341-364.

Thomsen, S. \& Pedersen, T. (2000). Ownership structure and economic performance in the largest European companies, Strategic Management Journal, 21(6): 689-705.

Thomsen, S., Pedersen, T. \& Kvist, H.K. (2006). Blockholder ownership: effects on firm value in market and control based governance systems, Journal of Corporate Finance, 12(1): 246-269.

Tribo, J.A., Berrone, P. \& Surroca, J. (2007). Do the type and number of blockholders influence R\&D investments? New evidence from Spain, Corporate Governance: An International Review, 15(5): 828-842.

Tribo, J.A. \& Casasola-Martinez, M.J. (2010). Banks as firms' blockholders: a study in Spain, Applied Financial Economics, 20(5): 425-438.

Unified Code of Good Corporate Governance (UCG) Code 2013. Spanish Securities Markets Commission, Madrid.

United Nations (2010). Corporate governance in the wake of the financial crisis-selected international views, New York and Geneva: United Nations.

Weinstein, D.E. \& Yafeh, Y. (1998). On the costs of a bank-centered financial system: Evidence from the changing main bank relations in Japan, Journal of Finance, 53(2): 635-672. 


\section{Bank power, Governance and Distress}

Table 1: Definition of dependent, independent and control variables.

\begin{tabular}{|c|c|}
\hline Variables & Definition \\
\hline FinDistress & $\begin{array}{l}\text { Our measure of financial distress is a dummy variable taking the value of } 1 \text { for } \\
\text { financially distressed firms, and } 0 \text { for the non-distressed (control) firms. }\end{array}$ \\
\hline \multicolumn{2}{|c|}{ Bank power and Governance variables } \\
\hline Bank power & $\begin{array}{l}\text { A dummy variable taking the value of } 1 \text { if the bank is both lender and shareholder in the } \\
\text { same firm, and } 0 \text { otherwise. This is obtained from the annual reports. }\end{array}$ \\
\hline Block ownership & $\begin{array}{l}\text { Denotes constructs that capture the power of all large non-dual bank blockholders } \\
\text { owning 5\% or more of the firm's outstanding shares at year t-2 relative to year of } \\
\text { financial distress. These constructs are: } \\
\text { (i) Total block share ownership - the combined ownership by all blockholders owning } \\
\text { at least } 5 \% \text { of shareholdings (Total blocks), which is then split in pressure sensitive } \\
\text { financial blocks (PresSensit blocks), pressure resistant financial blocks (PresResist } \\
\text { blocks), and non-financial blockholders (Non-financial blocks) } \\
\text { (ii) Blockholder dispersion, measured in the number of blocks and Herfindahl index (see } \\
\text { note } 4 \text { in the paper) } \\
\text { (iii) Top three largest block ownership-the total combined ownership of the top three } \\
\text { largest blockholders (Top3Blocks). This is also split into the individual top three } \\
\text { largest blockholders (Block 1, Block } 2 \text { and Block 3). }\end{array}$ \\
\hline Board independence & $\begin{array}{l}\text { Reflects the independence of the board as proxied by three constructs as follows: } \\
\text { (i) CEO/Chair - a dummy variable that takes the value of } 1 \text { if the roles of chairman and } \\
\text { CEO are combined, and } 0 \text { otherwise, at year t- } 2 \text { relative to year of financial distress. } \\
\text { (ii) Proprietary chair - a dummy variable that takes the value of } 1 \text { if the chairman is a } \\
\text { proprietary director and } 0 \text { otherwise, at year t- } 2 \text { relative to year of financial distress. } \\
\text { (iii) Outside directors - the proportion of outside directors, calculated as the number of } \\
\text { non-dual-bank outside directors scaled by the total number of directors on board of } \\
\text { directors at year t- } 2 \text { relative to year of financial distress. This is split into independent } \\
\text { directors and proprietary directors. }\end{array}$ \\
\hline $\begin{array}{l}\text { Block ownership*Bank power; } \\
\text { Board independence*Bank power }\end{array}$ & $\begin{array}{l}\text { The product of multiplying bank power by each of the corporate governance variables } \\
\text { as defined above. }\end{array}$ \\
\hline \multicolumn{2}{|l|}{ Control variables } \\
\hline Managerial ownership & $\begin{array}{l}\text { The percentage of shares directly held by all executive directors at the financial year-end } \\
\text { scaled by the total outstanding shares of the firm at year } t-2 \text { relative to year of financial } \\
\text { distress. }\end{array}$ \\
\hline Profitability & $\begin{array}{l}\text { The firm's earnings before interest and taxes for the year scaled by the replacement value } \\
\text { of total assets }{ }^{7} \text { at year t- } 2 \text { relative to year of financial distress (as in Pindado et al., 2008). }\end{array}$ \\
\hline
\end{tabular}

\footnotetext{
${ }^{7}$ According to Pindado et al. (2008), the replacement value of total assets ( $\left.\mathrm{RAT}_{\mathrm{it}}\right)$ is preferred because, unlike the book value of assets, it is not dependent upon accounting policies of the firm - thus it is less biased. Our computed is discussed in Pindado et al. (2008, p. 1002-1003) in the following way: $R A T_{i t}=R F_{i t}+\left(T A_{i t}-B F_{i t}\right)$, where $R F_{i t}$ is the replacement value of tangible fixed assets, $\mathrm{TA}_{\mathrm{it}}$ is the book value of total assets, and $\mathrm{BF}_{\mathrm{it}}$ is the book value of tangible fixed assets. Similar to Pindado et al. (2008), we obtain the book value of total assets (TA $\left.\mathrm{A}_{\mathrm{it}}\right)$ and the book value of tangible assets $\left(\mathrm{BF}_{\mathrm{it}}\right)$ from the balance sheet. $\mathrm{RF}_{\text {it }}$ is computed as: $\mathrm{RF}_{\text {it }}=\mathrm{RF}_{\mathrm{it}-1}\left[(1+\phi t) /\left(1+\delta_{\mathrm{it}}\right)\right]+\mathrm{I}_{i t} . \mathrm{RF}_{\mathrm{it} 0}=\mathrm{BF}_{\mathrm{it} 0}$ and t0 is the first year of the chosen period; $\delta_{i t}=\mathrm{D}_{\mathrm{it}} / \mathrm{BF}_{\mathrm{it}}$, where $\mathrm{D}_{\mathrm{it}}$ is the book depreciation expense and $\mathrm{BF}_{i t}$ is the book value of tangible fixed assets in the period $\mathrm{t}$; and $\left.\phi t=\left(\mathrm{GCGP}_{t}-\mathrm{GCGP}_{t-1}\right) / \mathrm{GCGP}_{t-1}\right)$ where $\mathrm{GCGP}_{t}$ is the growth of capital goods prices reported in the Main Economic Indicators published by the Organization for Economic Cooperation and Development (OECD). The data we use is obtained from firm's annual report and from the Spanish National Statistics Institute.
} 


\begin{tabular}{|l|l|}
\hline Financial expense & $\begin{array}{l}\text { Financial expense captures the leverage effect and is measured as interest paid for the } \\
\text { year scaled to the replacement value of total assets at year t-2 relative to year of financial } \\
\text { distress (see Pindado et al., 2008). We use the natural log to reduce the effects of outliers. }\end{array}$ \\
\hline Retained earnings & $\begin{array}{l}\text { Total retained earnings of a firm over its entire life scaled to the replacement value of } \\
\text { total assets (see Pindado et al., 2008), both measured at year t-3. The use of year t-3 in } \\
\text { calculating this variable is to avoid overlaps with the profitability measure above which } \\
\text { is measured at year t-2. }\end{array}$ \\
\hline
\end{tabular}

Table 2. Descriptive statistics of the sample

Panel A: Financially vs non-financially distressed firms (=184 firms)

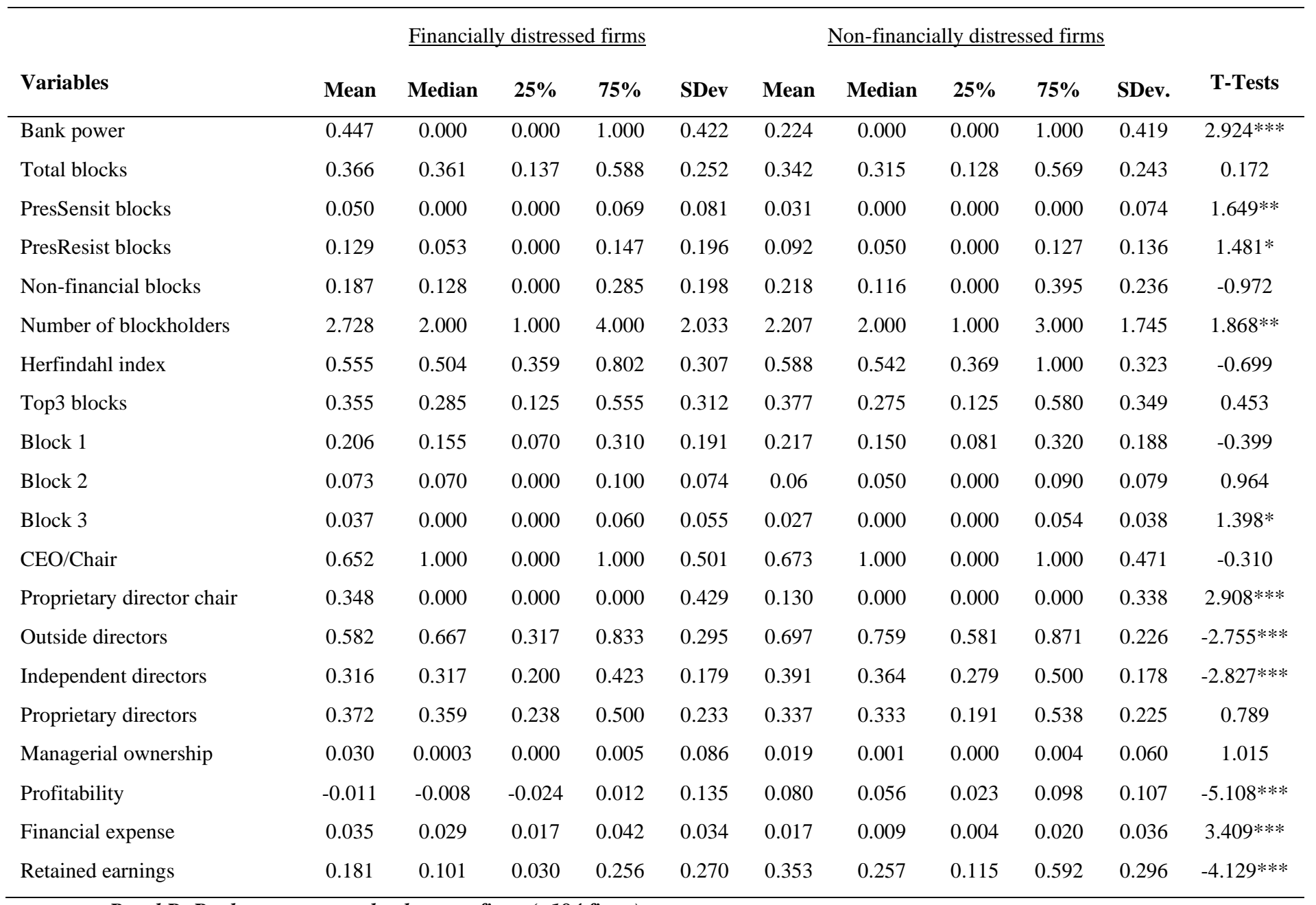

Panel B: Bank power vs non-bank power firms (=184 firms)

$\underline{\text { Bank Power firms }}$

Non-bank power firms

\begin{tabular}{lcccccccccccc} 
Variables & Mean & Median & $\mathbf{2 5 \%}$ & $\mathbf{7 5 \%}$ & SDev. & Mean & Median & 25\% & 75\% & SDev. & T-Tests \\
\hline Financial distress & 0.750 & 1.000 & 0.500 & 1.000 & 0.499 & 0.355 & 0.000 & 0.000 & 1.000 & 0.441 & $2.924 * * *$ \\
Total blocks & 0.388 & 0.380 & 0.206 & 0.567 & 0.205 & 0.348 & 0.327 & 0.124 & 0.584 & 0.254 & -0.561 \\
PresSensit blocks & 0.129 & 0.104 & 0.053 & 0.165 & 0.092 & 0.025 & 0.000 & 0.000 & 0.000 & 0.063 & $7.411^{* * *}$ \\
PresResist blocks & 0.087 & 0.053 & 0.000 & 0.091 & 0.140 & 0.115 & 0.050 & 0.000 & 0.136 & 0.174 & -0.804
\end{tabular}




\section{Bank power, Governance and Distress}

\begin{tabular}{lcccccccccccc} 
Non-financial blocks & 0.172 & 0.138 & 0.027 & 0.285 & 0.163 & 0.208 & 0.125 & 0.000 & 0.285 & 0.227 & -0.800 \\
Number of blockholders & 3.357 & 3.000 & 3.000 & 4.000 & 1.224 & 2.308 & 2.000 & 1.000 & 3.000 & 1.966 & $2.727^{* * *}$ \\
Herfindahl index & 0.571 & 0.506 & 0.445 & 0.649 & 0.244 & 0.572 & 0.507 & 0.359 & 1.000 & 0.327 & -0.014 \\
Top3 blocks & 0.331 & 0.235 & 0.12 & 0.450 & 0.328 & 0.373 & 0.280 & 0.125 & 0.580 & 0.331 & 0.611 \\
Block 1 & 0.142 & 0.095 & 0.000 & 0.225 & 0.151 & 0.224 & 0.160 & 0.081 & 0.325 & 0.193 & $-2.117^{* *}$ \\
Block 2 & 0.082 & 0.070 & 0.050 & 0.095 & 0.082 & 0.065 & 0.060 & 0.000 & 0.090 & 0.075 & 1.042 \\
Block 3 & 0.048 & 0.500 & 0.000 & 0.080 & 0.040 & 0.029 & 0.000 & 0.000 & 0.060 & 0.048 & $1.966^{* *}$ \\
CEO/Chair & 0.484 & 1.000 & 0.000 & 1.000 & 0.420 & 0.513 & 1.000 & 0.000 & 1.000 & 0.417 & -0.620 \\
Proprietary director chair & 0.516 & 0.000 & 0.000 & 0.000 & 0.390 & 0.098 & 0.000 & 0.000 & 0.000 & 0.360 & $-7.792^{* * *}$ \\
Outside directors & 0.343 & 0.326 & 0.191 & 0.483 & 0.212 & 0.693 & 0.775 & 0.586 & 0.871 & 0.242 & $-7.788^{* * *}$ \\
Independent directors & 0.315 & 0.286 & 0.146 & 0.456 & 0.198 & 0.360 & 0.333 & 0.250 & 0.444 & 0.178 & -1.215 \\
Proprietary directors & 0.283 & 0.275 & 0.152 & 0.410 & 0.181 & 0.367 & 0.344 & 0.211 & 0.542 & 0.237 & $-1.696^{* *}$ \\
Managerial ownership & 0.026 & 0.001 & 0.000 & 0.005 & 0.078 & 0.015 & 0.000 & 0.000 & 0.003 & 0.039 & -0.727 \\
Profitability & -0.002 & -0.002 & -0.013 & 0.031 & 0.015 & 0.056 & 0.041 & -0.007 & 0.068 & 0.138 & $-1.643^{*}$ \\
Financial expense & 0.027 & 0.019 & 0.004 & 0.034 & 0.032 & 0.022 & 0.018 & 0.006 & 0.032 & 0.069 & -0.687 \\
Retained earnings & 0.239 & 0.176 & 0.076 & 0.297 & 0.267 & 0.272 & 0.183 & 0.053 & 0.422 & 0.301 & -0.546 \\
\hline & & & & & & & & & & & &
\end{tabular}

***; **; and * Significant at the $1 \%, 5 \%$ and $10 \%$ levels, respectively; Bank power=a dummy taking the value of 1 if bank is both lender and equity-holder, and 0 otherwise; Bank power=a dummy taking the value of 1 if bank is both lender and equity-holder, and 0 otherwise; Total blocks $=\%$ shares owned by all non-dual bank blockholders; PresSensit blocks $=\%$ shares owned by pressure sensitive blocks (other than dual bank bank); PresResist blocks $=\%$ shares owned by pressure resistant blocks; Non-financial blocks $=\%$ shares owned by nonfinancial blockholders; Number of blocks=number of blocks; Herfindahl index=Herfindahl index of equity shares; Top3 blocks $=\%$ shares owned by the top three blockholders; Block 1, 2, 3=\% shares owned by first, second and third block, respectively; $C E O / C h a i r$ duality=a dummy variable that takes the value of 1 for role duality, and 0 otherwise; Proprietary director chair=a dummy variable that takes the value of 1 for proprietary chair, and 0 otherwise; Outside boards $=\%$ non-dual bank outside directors; Independence directors $=\%$ of independent directors on the board; Proprietary directors $=\%$ of non-dual bank proprietary directors; Managerial ownership $=\%$ shares held by executive directors; Profitability=PBIT scaled by the replacement value of total assets; Financial expense=interest paid scaled by the replacement value of total assets; Retained earnings=total retained earnings scaled by the replacement value of total assets. 


\section{Bank power, Governance and Distress}

Table 3: Correlation matrix

\begin{tabular}{|c|c|c|c|c|c|c|c|c|c|c|c|c|c|c|}
\hline Variable & 1 & 2 & 3 & 4 & 5 & 6 & 7 & 8 & 9 & 10 & 11 & 12 & 13 & 14 \\
\hline 1. Bank power & 1.000 & & & & & & & & & & & & & \\
\hline 2. Total blocks & -.058 & 1.000 & & & & & & & & & & & & \\
\hline 3. PresSensit blocks & -.031 & .250 & 1.000 & & & & & & & & & & & \\
\hline 4. PresResist blocks & -.060 & .426 & -.019 & 1.000 & & & & & & & & & & \\
\hline 5. Non-financial blocks & -.059 & .689 & .072 & -.288 & 1.000 & & & & & & & & & \\
\hline 6. CEO/Chair & -.046 & .076 & .153 & .056 & -.093 & 1.000 & & & & & & & & \\
\hline 7. Proprietary director chair & -.007 & -.038 & -.103 & .003 & .211 & -.568 & 1.000 & & & & & & & \\
\hline 8. Outside directors & -.399 & .045 & -.399 & .118 & .038 & -.117 & .078 & 1.000 & & & & & & \\
\hline 9. Independent directors & -.089 & -.045 & -.116 & -.052 & -.007 & .126 & -.171 & .336 & 1.000 & & & & & \\
\hline 10. Proprietary directors & -.125 & .321 & .141 & .184 & .202 & -.230 & .219 & .249 & -.453 & 1.000 & & & & \\
\hline 11. Managerial ownership & -.054 & -.111 & -.069 & -.110 & -.033 & .055 & -.062 & -.018 & .026 & -.146 & 1.000 & & & \\
\hline 12. Profitability & -.120 & -.015 & .024 & .035 & -.042 & -.007 & -.045 & .153 & -.067 & .112 & -.090 & 1.000 & & \\
\hline 13. Financial expense & -.051 & -.066 & -.089 & .005 & -.076 & -.103 & .165 & .057 & -.111 & .102 & .070 & -.164 & 1.000 & \\
\hline 14. Retained earnings & -.040 & -.038 & -.013 & .059 & -.086 & .262 & -.239 & .107 & .054 & -.009 & .012 & .225 & -.0051 & 1.000 \\
\hline
\end{tabular}

Bank power =a dummy taking the value of 1 if bank is both lender and equity-holder, and 0 otherwise; Total blocks $=\%$ shares owned by all nondual bank blockholders; PresSensit blocks = \% shares owned by pressure sensitive blocks (other than dual bank bank); PresResist blocks $=\%$ shares owned by pressure resistant blocks; Non-financial blocks $=\%$ shares owned by nonfinancial blockholders; CEO/Chair duality=a dummy variable that takes the value of 1 for role duality, and 0 otherwise; Proprietary director chair=a dummy variable that takes the value of 1 for proprietary chair, and 0 otherwise; Outside boards $=\%$ non-dual bank outside directors; Independence directors $=\%$ of independent directors on the board; Proprietary directors $=\%$ of non-dual bank proprietary directors; Managerial ownership $=\%$ shares held by executive directors; Profitability $=$ PBIT scaled by the replacement value of total assets; Financial expense=interest paid scaled by the replacement value of total assets; Retained earnings=total retained earnings scaled by the replacement value of total assets. 


\section{Bank power, Governance and Distress}

Table 4: Results of conditional logistic regression on the effects of bank power and corporate governance structure on financial distress likelihood: Reduced Equation 1

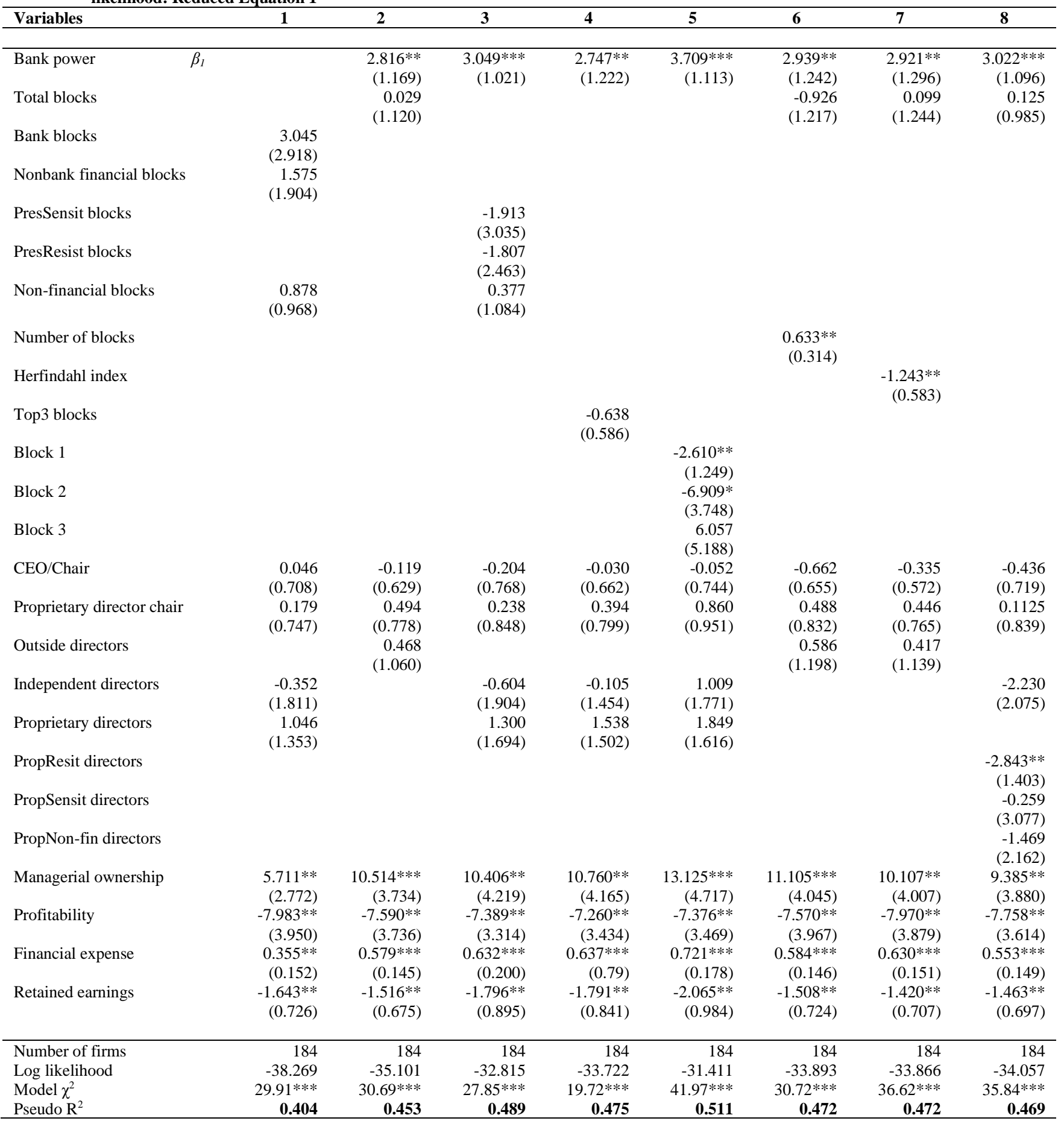

Robust standard errors in parentheses; ***;**; and * Significant at the $1 \%, 5 \%$ and $10 \%$ levels, respectively; Bank power=a dummy taking the value of 1 if bank is both lender and equity-holder, and 0 otherwise; **; **; and * Significant at the $1 \%, 5 \%$ and $10 \%$ levels, respectively; Bank power=a dummy taking the value of 1 if bank is both lender and equityholder, and 0 otherwise; Bank power=a dummy taking the value of 1 if bank is both lender and equity-holder, and 0 otherwise; Total blocks $=\%$ shares owned by all non-dual bank blockholders; PresSensit blocks $=\%$ shares owned by pressure sensitive blocks (other than dual bank bank); PresResist blocks=\% shares owned by pressure resistant blocks; Nonfinancial blocks $=\%$ shares owned by nonfinancial blockholders; Number of blocks=number of blocks; Herfindahl index $=$ Herfindahl index of equity shares; Top 3 blocks $=\%$ shares owned by the top three blockholders; Block $1,2,3=\%$ shares owned by first, second and third block, respectively; CEO/Chair duality=a dummy variable that takes the value of 1 for role duality, and 0 otherwise; Proprietary director chair=a dummy variable that takes the value of 1 for proprietary chair, and 0 otherwise; Outside boards $=\%$ non-dual bank outside directors; Independence directors $=\%$ of independent directors on the board; Proprietary directors $=\%$ of non-dual bank proprietary directors; Managerial ownership $=\%$ shares held by executive directors; Profitability=PBIT scaled by the replacement value of total assets; Financial expense=interest paid scaled by the replacement value of total assets; Retained earnings=total retained earnings scaled by the replacement value of total assets. 
Bank power, Governance and Distress

Table 5: Results of conditional logistic regression on the effects of bank power and corporate governance structure on financial distress likelihood: Moderation model

\begin{tabular}{|c|c|c|c|c|c|c|c|}
\hline Variables & 1 & 2 & 3 & 4 & 5 & 6 & 7 \\
\hline \multicolumn{8}{|c|}{ Panel A: Individual and moderation effects } \\
\hline Bank power & $\begin{array}{r}2.703 * * \\
(1.258)\end{array}$ & $\begin{array}{r}3.563 * * \\
(1.485)\end{array}$ & $\begin{array}{r}3.363 * * \\
(1.588)\end{array}$ & $\begin{array}{l}2.258^{*} \\
(1.233)\end{array}$ & $\begin{array}{r}2.652 * * \\
(1.314)\end{array}$ & $\begin{array}{r}3.155^{* *} \\
(1.413)\end{array}$ & $\begin{array}{r}4.357 \text { *** } \\
(1.757)\end{array}$ \\
\hline Total blocks & $\begin{array}{r}0.310 \\
(1.249)\end{array}$ & & & & $\begin{array}{r}-1.197 \\
(1.532)\end{array}$ & $\begin{array}{r}0.161 \\
(1.550)\end{array}$ & $\begin{array}{r}0.469 \\
(1.031)\end{array}$ \\
\hline PresSensit blocks & & $\begin{array}{r}-0.659 \\
(4.089)\end{array}$ & & & & & \\
\hline PresResist blocks & & $\begin{array}{r}-3.017 \\
(2.831)\end{array}$ & & & & & \\
\hline Non-financial blocks & & $\begin{array}{r}0.336 \\
(1.088)\end{array}$ & & & & & \\
\hline Number of blocks & & & & & $\begin{array}{r}0.781 * * \\
(0.396)\end{array}$ & & \\
\hline Herfindahl index & & & & & & $\begin{array}{r}-1.524 * * \\
(0.727)\end{array}$ & \\
\hline Top3 blocks & & & $\begin{array}{r}-0.287 \\
(0.670)\end{array}$ & & & & \\
\hline Block 1 & & & & $\begin{array}{r}-3.123 * * \\
(1.518)\end{array}$ & & & \\
\hline Block 2 & & & & $\begin{array}{r}-9.658 * \\
(5.460)\end{array}$ & & & \\
\hline Block 3 & & & & $\begin{array}{r}5.817 \\
(6.462)\end{array}$ & & & \\
\hline $\mathrm{CEO} /$ Chair & $\begin{array}{r}-0.188 \\
(0.739)\end{array}$ & $\begin{array}{r}-0.515 \\
(1.024)\end{array}$ & $\begin{array}{r}-0.265 \\
(0.827)\end{array}$ & $\begin{array}{r}-0.647 \\
(0.996)\end{array}$ & $\begin{array}{r}-0.671 \\
(0.858)\end{array}$ & $\begin{array}{r}-0.556 \\
(0.683)\end{array}$ & $\begin{array}{c}-0.494 \\
(0.887)\end{array}$ \\
\hline Proprietary director chair & $\begin{array}{r}0.409 \\
(0.910)\end{array}$ & $\begin{array}{r}-0.160 \\
(1.129)\end{array}$ & $\begin{array}{r}0.214 \\
(0.962)\end{array}$ & $\begin{array}{r}0.455 \\
(1.183)\end{array}$ & $\begin{array}{r}0.134 \\
(1.026)\end{array}$ & $\begin{array}{r}0.232 \\
(0.905)\end{array}$ & $\begin{array}{r}0.106 \\
(1.078)\end{array}$ \\
\hline Outside directors & $\begin{array}{r}0.376 \\
(1.247)\end{array}$ & & & & $\begin{array}{r}0 . .273 \\
(1.494)\end{array}$ & $\begin{array}{r}0.257 \\
(1.448)\end{array}$ & \\
\hline Independent directors & & $\begin{array}{r}-1.512 \\
(2.202)\end{array}$ & $\begin{array}{r}-0.875 \\
(1.638)\end{array}$ & $\begin{array}{r}-0.388 \\
(2.126)\end{array}$ & & & $\begin{array}{r}-2.361 \\
(2.087)\end{array}$ \\
\hline Proprietary directors & & $\begin{array}{r}1.059 \\
(1.804)\end{array}$ & $\begin{array}{r}1.591 \\
(1.702)\end{array}$ & $\begin{array}{r}1.832 \\
(2.066)\end{array}$ & & & \\
\hline PropResit directors & & & & & & & $\begin{array}{r}-2.477 * * \\
(2.214)\end{array}$ \\
\hline PropSensit directors & & & & & & & $\begin{array}{r}0.933 \\
(3.084)\end{array}$ \\
\hline PropNon-fin directors & & & & & & & $\begin{array}{c}-0.608 \\
(2.278)\end{array}$ \\
\hline Managerial ownership & $\begin{array}{r}10.684 * * * \\
(4.000)\end{array}$ & $\begin{array}{r}11.158 * * \\
(4.523)\end{array}$ & $\begin{array}{r}11.578 * * \\
(4.56)\end{array}$ & $\begin{array}{r}16.936^{* * *} \\
(6.543)\end{array}$ & $\begin{array}{r}12.263 * * \\
(4.891)\end{array}$ & $\begin{array}{r}13.337 * * \\
(5.392)\end{array}$ & $\begin{array}{r}11.382 * * \\
(4.788)\end{array}$ \\
\hline Profitability & $\begin{array}{r}-7.692 * * \\
(3.908)\end{array}$ & $\begin{array}{r}-7.553^{* *} \\
(3.349)\end{array}$ & $\begin{array}{r}-7.592 * * \\
(3.642)\end{array}$ & $\begin{array}{r}-8.253 * * \\
(3.453)\end{array}$ & $\begin{array}{r}-9.869^{*} \\
(4.469)\end{array}$ & $\begin{array}{r}-8.561 * \\
(4.435)\end{array}$ & $\begin{array}{r}-8.321 * * \\
(3.909)\end{array}$ \\
\hline Financial expense & $\begin{array}{r}0.587 * * * * \\
(0.144)\end{array}$ & $\begin{array}{r}0.533^{* * * *} \\
(0.197)\end{array}$ & $\begin{array}{r}0.613^{* * * *} \\
(0.178)\end{array}$ & $\begin{array}{r}0.819 * * * \\
(0.260)\end{array}$ & $\begin{array}{r}0.602 * * * \\
(0.153)\end{array}$ & $\begin{array}{r}0.701 * * * \\
(0.158)\end{array}$ & $\begin{array}{r}0.551 * * * \\
(0.147)\end{array}$ \\
\hline Retained earnings & $\begin{array}{r}-1.379 * * \\
(0.692)\end{array}$ & $\begin{array}{r}-2.236^{* * *} \\
(0.941)\end{array}$ & $\begin{array}{r}-1.904 * * \\
(0.924)\end{array}$ & $\begin{array}{r}-2.679 * * \\
(1.171)\end{array}$ & $\begin{array}{r}-1.672 * * \\
(0.750)\end{array}$ & $\begin{array}{r}-1.701 * * \\
(0.806)\end{array}$ & $\begin{array}{r}-1.597 * * \\
(0.803)\end{array}$ \\
\hline Total blocks*Bank power $\beta_{20}$ & $\begin{array}{r}-5.829 * * \\
(3.461)\end{array}$ & & & & $\begin{array}{r}-6.757 * * \\
(3.356)\end{array}$ & $\begin{array}{l}-6.597 * * \\
\quad(3.235)\end{array}$ & $\begin{array}{r}-4.851 * * \\
(2.453)\end{array}$ \\
\hline PresSensit blocks*Bank power $\beta_{21}$ & & $\begin{array}{r}-10.781 \\
(8.208)\end{array}$ & & & & & \\
\hline PresResist blocks*Bank power $\beta_{22}$ & & $\begin{array}{r}-9.533^{* *} \\
(4.085)\end{array}$ & & & & & \\
\hline Non-financial blocks*Bank power $\beta_{23}$ & & $\begin{array}{r}-2.519 \\
(3.687)\end{array}$ & & & & & \\
\hline Number of blocks*Bank power $\beta_{24}$ & & & & & $\begin{array}{r}2.286^{* *} \\
(1.154)\end{array}$ & & \\
\hline Herfindahl*Bank power $\quad \beta_{25}$ & & & & & & $\begin{array}{r}-6.341 * * \\
(2.995)\end{array}$ & \\
\hline Top3 blocks*Bank power $\beta_{26}$ & & & $\begin{array}{r}-2.649 \\
(2.805)\end{array}$ & & & & \\
\hline Block $1 *$ Bank power & & & & $\begin{array}{r}-16.446^{* *} \\
(7.095)\end{array}$ & & & \\
\hline Block $2 *$ Bank power & & & & $\begin{array}{l}-1.554 \\
(6.425)\end{array}$ & & & \\
\hline
\end{tabular}




\section{Bank power, Governance and Distress}

\begin{tabular}{|c|c|c|c|c|c|c|c|}
\hline Block 3*Bank power $\quad \beta_{29}$ & & & & $\begin{array}{r}-12.925 \\
(13.322)\end{array}$ & & & \\
\hline CEO/Chair*Bank power $\beta_{30}$ & $\begin{array}{r}0.268 \\
(1.589)\end{array}$ & $\begin{array}{r}1.491 \\
(1.403)\end{array}$ & $\begin{array}{r}1.401 \\
(1.432)\end{array}$ & $\begin{array}{r}2.604 \\
(1.807)\end{array}$ & $\begin{array}{r}0.924 \\
(1.616)\end{array}$ & $\begin{array}{r}0.188 \\
(1.545)\end{array}$ & $\begin{array}{r}-1.948 \\
(1.859)\end{array}$ \\
\hline Proprietary director chair*Bank power $\beta_{31}$ & $\begin{array}{r}11.666 * * * * \\
(1.948)\end{array}$ & $10.459 * * *$ & $\begin{array}{r}9.755^{* * * *} \\
(2.109)\end{array}$ & $\begin{array}{r}17.607 * * * \\
(3.369)\end{array}$ & $\begin{array}{r}11.926 * * * \\
(2.173)\end{array}$ & $\begin{array}{r}12.613 * * * \\
(1.981)\end{array}$ & $\begin{array}{r}11.865^{* * * *} \\
(1.622)\end{array}$ \\
\hline Outside directors *Bank power $\beta_{32}$ & $\begin{array}{r}-6.499 * \\
(3.613)\end{array}$ & & & & $\begin{array}{l}-6.209^{*} \\
(3.718)\end{array}$ & $\begin{array}{r}-6.772^{*} \\
(4.031)\end{array}$ & \\
\hline Independent directors*Bank power $\beta_{33}$ & & $\begin{array}{r}-3.531 \\
(5.048)\end{array}$ & $\begin{array}{r}-2.762 \\
(5.903)\end{array}$ & $\begin{array}{r}3.422 \\
(6.117)\end{array}$ & & & $\begin{array}{r}-6.661 \\
(6.849)\end{array}$ \\
\hline Proprietary directors*Bank power $\beta_{34}$ & & $\begin{array}{r}-13.368^{* *} \\
(5.616)\end{array}$ & $\begin{array}{r}-11.314^{*} \\
(5.839)\end{array}$ & $\begin{array}{r}-10.871 * * \\
(5.199)\end{array}$ & & & \\
\hline PropResit directors*Bank power & & & & & & & $\begin{array}{r}-11.719 * * \\
(5.715)\end{array}$ \\
\hline PropSensit directors*Bank power & & & & & & & $\begin{array}{r}-12.387 \\
(8.344)\end{array}$ \\
\hline PropNon-fin directors*Bank power & & & & & & & $\begin{array}{r}-7.373 \\
(4.990)\end{array}$ \\
\hline Number of firms & 184 & 184 & 184 & 184 & 184 & 184 & 184 \\
\hline Log likelihood & -34.603 & -29.516 & -31.605 & -26.780 & -32.880 & -31.927 & -31.823 \\
\hline Model $\chi^{2}$ & $776.46^{* * * *}$ & $464.31 * * *$ & $516.27 * * *$ & $284.72 * * *$ & $693.54 * * *$ & $605.54 * * *$ & $398.20 * * *$ \\
\hline Pseudo $\mathrm{R}^{2}$ & 0.461 & 0.540 & 0.508 & 0.583 & 0.488 & 0.503 & 0.504 \\
\hline \multicolumn{8}{|c|}{ Panel B: Wald tests of total effects of bank power } \\
\hline $\begin{array}{l}\left(\boldsymbol{\beta}_{1}+\boldsymbol{\beta}_{20}\right) \\
\left(\boldsymbol{\beta}_{1}+\boldsymbol{\beta}_{21}\right) \\
\left(\boldsymbol{\beta}_{1}+\boldsymbol{\beta}_{22}\right) \\
\left(\boldsymbol{\beta}_{1}+\boldsymbol{\beta}_{23}\right) \\
\left(\boldsymbol{\beta}_{1}+\boldsymbol{\beta}_{24}\right) \\
\left(\boldsymbol{\beta}_{1}+\boldsymbol{\beta}_{25}\right) \\
\left(\boldsymbol{\beta}_{1}+\boldsymbol{\beta}_{26}\right) \\
\left(\boldsymbol{\beta}_{1}+\boldsymbol{\beta}_{27}\right) \\
\left(\boldsymbol{\beta}_{1}+\boldsymbol{\beta}_{28}\right) \\
\left(\boldsymbol{\beta}_{1}+\boldsymbol{\beta}_{29}\right) \\
\left(\boldsymbol{\beta}_{1}+\boldsymbol{\beta}_{30}\right) \\
\left(\boldsymbol{\beta}_{1}+\boldsymbol{\beta}_{31}\right) \\
\left(\boldsymbol{\beta}_{1}+\boldsymbol{\beta}_{32}\right) \\
\left(\boldsymbol{\beta}_{1}+\boldsymbol{\beta}_{33}\right) \\
\left(\boldsymbol{\beta}_{1}+\boldsymbol{\beta}_{34}\right)\end{array}$ & $\begin{array}{r}2.971 * \\
14.368 * * * \\
-3.796\end{array}$ & $\begin{array}{r}2.072 * \\
14.022^{* * *} \\
\\
0.032 \\
-9.803^{*}\end{array}$ & $\begin{array}{r}1.962 * \\
13.118 * * * \\
\\
0.601 \\
-7.952 *\end{array}$ & $\begin{array}{r}-13.888^{*} \\
1.004 \\
-10.367 \\
5.162^{*} \\
20.165 * * \\
\\
5.980 \\
-8.6313^{*}\end{array}$ & $\begin{array}{r}3.576^{* *} \\
14.578^{* * *} \\
-3.557\end{array}$ & $\begin{array}{r}2.967 * * \\
15.768^{* * * *} \\
-3.617\end{array}$ & \\
\hline $\begin{array}{l}\text { Robust standard errors in parentheses; } * * * ; * * ; \text { an } \\
\text { and equity-holder, and } 0 \text { otherwise; } * * * ; * * ; \text { and } * \\
\text { equity-holder, and } 0 \text { otherwise; } \text { Bank power }=\text { a dun } \\
\text { dual bank blockholders; PresSensit blocks }=\% \text { sha } \\
\text { blocks; } \text { Non-financial blocks }=\% \text { shares owned by } \\
\text { blocks }=\% \text { shares owned by the top three blockhol } \\
\text { takes the value of } 1 \text { for role duality, and } 0 \text { otherwise } \\
\% \text { non-dual bank outside directors; Independence } \\
\text { ownership }=\% \text { shares held by executive directors; } \\
\text { value of total assets; Retained earnings }=\text { total retain }\end{array}$ & $\begin{array}{l}\text { nificant at the } \\
\text { icant at the } 1 \% \text {, } \\
\text { king the value } \\
\text { ned by pressure } \\
\text { nancial blockho } \\
\text { lock } 1,2,3=\% \\
\text { rietary director } \\
\text { s=\% of indeper } \\
\text { bility }=P B I T \text { sc } \\
\text { nings scaled by }\end{array}$ & $\begin{array}{l}5 \% \text { and } 10 \% 1 \\
\% \text { and } 10 \% \text { leve } \\
1 \text { if bank is both } \\
\text { nsitive blocks } \\
\text { ers; Number of } \\
\text { tares owned by } \\
\text { air =a dummy } \\
\text { th directors on } \\
\text { d by the replace } \\
\text { e replacement }\end{array}$ & $\begin{array}{l}\text { Is, respectivel } \\
\text { respectively; } \\
\text { der and equity } \\
\text { er than dual b } \\
\text { cks=number } \\
\text { t, second and } \\
\text { able that takes } \\
\text { board; } \text { Propric } \\
\text { nt value of to } \\
\text { e of total asse }\end{array}$ & $\begin{array}{l}\text { Bank power }=\mathrm{a} \\
\text { k power }=\mathrm{a} \text { dun } \\
\text { older, and } 0 \text { oth } \\
\mathrm{k} \text { bank); PresR } \\
\text { locks; Herfind } \\
\text { ird block, respe } \\
\text { e value of } 1 \text { for } \\
\text { ry directors }=\% \\
\text { assets; Financi }\end{array}$ & $\begin{array}{l}\text { nmy taking th } \\
\text { taking the va } \\
\text { vise; Total blo } \\
\text { blocks }=\% \mathrm{st} \\
\text { index }=\text { Herfin } \\
\text { ely; CEO/Cha } \\
\text { prietary chair, } \\
\text { on-dual bank } \\
\text { xpense=intere }\end{array}$ & $\begin{array}{l}\text { lue of } 1 \text { if ban } \\
\text { of } 1 \text { if bank is } \\
=\% \text { shares ow } \\
\text { owned by pr } \\
\text { index of equit } \\
\text { uality=a dumn } \\
0 \text { otherwise; } O \\
\text { prietary directo } \\
\text { aid scaled by t }\end{array}$ & $\begin{array}{l}\text { s both lender } \\
\text { th lender and } \\
\text { d by all non- } \\
\text { sure resistant } \\
\text { shares; Top3 } \\
\text { variable that } \\
\text { side boards } \\
\text {; Managerial } \\
\text { replacement }\end{array}$ \\
\hline
\end{tabular}


Bank power, Governance and Distress

Table 6: Endogeneity tests: Two-stage Heckman Model

\begin{tabular}{|c|c|c|c|c|c|c|}
\hline Variables & $\mathbf{1}$ & 2 & 3 & 4 & 5 & 6 \\
\hline Log total assets & $\begin{array}{l}0.275^{*} \\
(0.164)\end{array}$ & & & & & \\
\hline Bank power & & $\begin{array}{r}2.712 * * \\
(1.432)\end{array}$ & $\begin{array}{r}3.519 * * \\
(1.505)\end{array}$ & $\begin{array}{r}2.639 * * \\
(1.362)\end{array}$ & $\begin{array}{r}3.245 * * \\
(1.428)\end{array}$ & $\begin{array}{l}2.301^{*} \\
(1.354)\end{array}$ \\
\hline Total blocks & & $\begin{array}{r}0.231 \\
(1.455)\end{array}$ & & $\begin{array}{l}-1.144 \\
(1.744)\end{array}$ & $\begin{array}{l}-0.251 \\
(1.755)\end{array}$ & \\
\hline PresSensit blocks & $\begin{array}{r}9.807 * * \\
(4.115)\end{array}$ & & $\begin{array}{r}-0.334 \\
(4.707)\end{array}$ & & & \\
\hline PresResist blocks & $\begin{array}{r}-1.078 \\
(1.082)\end{array}$ & & $\begin{array}{r}-3.074 \\
(2.748)\end{array}$ & & & \\
\hline Non-financial blocks & $\begin{array}{r}0.488 \\
(0.784)\end{array}$ & & $\begin{array}{r}0.336 \\
(1.105)\end{array}$ & & & \\
\hline Number of blocks & & & & $\begin{array}{r}0.785 * * \\
(0.391)\end{array}$ & & \\
\hline Herfindahl index & & & & & $\begin{array}{r}-1.577 * * \\
(0.823)\end{array}$ & \\
\hline Block 1 & & & & & & $\begin{array}{r}-3.209 * \\
(1.652)\end{array}$ \\
\hline Block 2 & & & & & & $\begin{array}{r}-9.715^{*} \\
(5.295)\end{array}$ \\
\hline Block 3 & & & & & & $\begin{array}{r}6.188 \\
(6.815)\end{array}$ \\
\hline CEO/Chair & $\begin{array}{r}0.204 \\
(0.771)\end{array}$ & $\begin{array}{r}-0.197 \\
(0.749)\end{array}$ & $\begin{array}{r}-0.519 \\
(1.027)\end{array}$ & $\begin{array}{r}-0.667 \\
(0.870)\end{array}$ & $\begin{array}{r}-0.624 \\
(0.701)\end{array}$ & $\begin{array}{l}-0.642 \\
(0.998)\end{array}$ \\
\hline Proprietary director chair & $\begin{array}{r}-0.149 \\
(0.777)\end{array}$ & $\begin{array}{r}0.407 \\
(0.910)\end{array}$ & $\begin{array}{r}-0.174 \\
(1.138)\end{array}$ & $\begin{array}{r}0.135 \\
(1.028)\end{array}$ & $\begin{array}{r}0.203 \\
(0.899)\end{array}$ & $\begin{array}{r}0.489 \\
(1.225)\end{array}$ \\
\hline Outside directors & $\begin{array}{r}-2.109 * * * \\
(0.724)\end{array}$ & $\begin{array}{r}0.249 \\
(1.633)\end{array}$ & & $\begin{array}{r}0.367 \\
(1.876)\end{array}$ & $\begin{array}{r}-0.399 \\
(2.001)\end{array}$ & \\
\hline Independent directors & & & $\begin{array}{r}-1.262 \\
(2.902)\end{array}$ & & & $\begin{array}{l}-0.615 \\
(2.610)\end{array}$ \\
\hline Proprietary directors & & & $\begin{array}{r}1.320 \\
(2.593)\end{array}$ & & & $\begin{array}{r}1.583 \\
(2.335)\end{array}$ \\
\hline Managerial ownership & $\begin{array}{r}2.916 \\
(3.424)\end{array}$ & $\begin{array}{r}10.502 * * \\
(4.202)\end{array}$ & $\begin{array}{r}11.700 * * \\
(5.629)\end{array}$ & $\begin{array}{r}12.408 * * \\
(4.913)\end{array}$ & $\begin{array}{r}12.521 * * \\
(5.687)\end{array}$ & $\begin{array}{r}16.516^{* * *} \\
(6.721)\end{array}$ \\
\hline Profitability & $\begin{array}{l}-1.973 * \\
(1.055)\end{array}$ & $\begin{array}{r}-7.785 * * \\
(3.893)\end{array}$ & $\begin{array}{r}-7.335^{* *} * \\
(3.054)\end{array}$ & $\begin{array}{r}-7.800^{*} \\
(4.484)\end{array}$ & $\begin{array}{r}-9.127 * * \\
(4.564)\end{array}$ & $\begin{array}{r}-8.561 * * * \\
(3.084)\end{array}$ \\
\hline Financial expense & $\begin{array}{r}0.199 * * \\
(0.103)\end{array}$ & $\begin{array}{r}0.574 * * * \\
(0.181)\end{array}$ & $\begin{array}{r}0.558 * * \\
(0.256)\end{array}$ & $\begin{array}{r}0.612 * * * \\
(0.180)\end{array}$ & $\begin{array}{r}0.645 * * * \\
(0.185)\end{array}$ & $\begin{array}{r}0.796 * * * * \\
(0.267)\end{array}$ \\
\hline Retained earnings & $\begin{array}{r}-0.302 * * \\
(0.134)\end{array}$ & $\begin{array}{r}-1.340 * * \\
(0.689)\end{array}$ & $\begin{array}{r}-2.304 * * \\
(1.068)\end{array}$ & $\begin{array}{r}-1.702 * * \\
(0.734)\end{array}$ & $\begin{array}{r}-1.498 * * \\
(0.716)\end{array}$ & $\begin{array}{r}-2.606^{* * *} \\
(1.181)\end{array}$ \\
\hline Total blocks*Bank power & & $\begin{array}{r}-6.832 * * \\
(3.485)\end{array}$ & & $\begin{array}{r}-6.470 * * \\
(3.354)\end{array}$ & $\begin{array}{r}-6.648 * * \\
(3.283)\end{array}$ & \\
\hline PresSensit blocks*Bank power & & & $\begin{array}{r}-10.495 \\
(8.291)\end{array}$ & & & \\
\hline PresResist blocks*Bank power & & & $\begin{array}{r}-9.594 * * \\
(4.050)\end{array}$ & & & \\
\hline Non-financial blocks*Bank power & & & $\begin{array}{r}-2.571 \\
(3.763)\end{array}$ & & & \\
\hline Number of blocks*Bank power & & & & $\begin{array}{l}1.992^{*} \\
(1.105)\end{array}$ & & \\
\hline Herfindahl index*Bank power & & & & & $\begin{array}{r}-6.653 * * \\
(3.077)\end{array}$ & \\
\hline Block 1*Bank power & & & & & & $\begin{array}{r}-16.859 * * \\
(6.811)\end{array}$ \\
\hline Block $2 *$ Bank power & & & & & & $\begin{array}{r}-1.457 \\
(6.139)\end{array}$ \\
\hline Block $3 *$ Bank power & & & & & & $\begin{array}{r}-13.175 \\
(12.837)\end{array}$ \\
\hline CEO/Chair*Bank power & & $\begin{array}{r}0.264 \\
(1.584)\end{array}$ & $\begin{array}{r}1.493 \\
(1.407)\end{array}$ & $\begin{array}{r}0.930 \\
(1.609)\end{array}$ & $\begin{array}{r}0.195 \\
(1.528)\end{array}$ & $\begin{array}{r}2.736 \\
(1.742)\end{array}$ \\
\hline Proprietary director chair*Bank power & & $\begin{array}{r}13.600 * * * \\
(1.949)\end{array}$ & $\begin{array}{r}9.723 * * * \\
(2.168)\end{array}$ & $\begin{array}{r}12.669 * * * \\
(2.165)\end{array}$ & $\begin{array}{r}12.636^{* * * *} \\
(2.018)\end{array}$ & $\begin{array}{r}16.575^{* * *} \\
(3.309)\end{array}$ \\
\hline Outside directors*Bank power & & $\begin{array}{r}-2.575^{*} \\
(1.506)\end{array}$ & & $\begin{array}{l}-2.555^{*} \\
(1.530)\end{array}$ & $\begin{array}{l}-3.369^{*} \\
(1.914)\end{array}$ & \\
\hline
\end{tabular}




\section{Bank power, Governance and Distress}

$\begin{aligned} & \text { Independent directors*Bank power } \\ & \text { Proprietary directors*Bank power }\end{aligned}$
$\begin{aligned} & \text { Y } \\ & \text { Industry controls }\end{aligned}$
Constant




\section{Bank power, Governance and Distress}

Table 7: Results of conditional logistic regression on the effects of bank power and corporate governance structures on financial dist ress likelihood: Re-estimation with Z-scores

\begin{tabular}{|c|c|c|c|c|c|}
\hline Variables & 1 & 2 & 3 & 4 & 5 \\
\hline \multirow[t]{2}{*}{ Bank power } & $16.879 * * *$ & $21.648 * * *$ & $17.242 * * *$ & $18.427 * * *$ & $18.197 * * *$ \\
\hline & $(2.366)$ & $(4.413)$ & $(2.503)$ & $(2.802)$ & $(2.556)$ \\
\hline \multirow[t]{2}{*}{ Total blocks } & -0.061 & & 1.272 & -0.529 & \\
\hline & $(0.794)$ & & $(1.000)$ & $(0.819)$ & \\
\hline \multirow[t]{2}{*}{ PresSensit blocks } & & -4.046 & & & \\
\hline & & $(2.761)$ & & & \\
\hline \multirow[t]{2}{*}{ PresResist blocks } & & -0.447 & & & \\
\hline & & $(1.278)$ & & & \\
\hline \multirow{2}{*}{ Non-financial blocks } & & 0.295 & & & \\
\hline & & $(0.925)$ & & & \\
\hline \multirow{2}{*}{ Number of blocks } & & & $0.882 * * *$ & & \\
\hline & & & $(0.321)$ & & \\
\hline \multirow[t]{2}{*}{ Herfindahl index } & & & & $-1.854 * * *$ & \\
\hline & & & & $(0.645)$ & \\
\hline \multirow[t]{2}{*}{ Block 1} & & & & & -1.882 \\
\hline & & & & & (1.195) \\
\hline \multirow[t]{2}{*}{ Block 2} & & & & & -1.722 \\
\hline & & & & & $(3.472)$ \\
\hline \multirow{2}{*}{ Block 3} & & & & & 12.440 \\
\hline & & & & & $(5.686)$ \\
\hline \multirow[t]{2}{*}{ CEO/Chair } & 0.095 & 0.132 & 0.265 & 0.221 & 0.045 \\
\hline & $(0.535)$ & $(0.562)$ & $(0.571)$ & $(0.589)$ & $(0.608)$ \\
\hline \multirow[t]{2}{*}{ Proprietary director chair } & -0.074 & -0.098 & -0.135 & -0.172 & -0.394 \\
\hline & $(0.679)$ & $(0.713)$ & $(0.708)$ & $(0.737)$ & $(762)$ \\
\hline \multirow{2}{*}{ Outside directors } & 0.726 & & 0.530 & 0.605 & 0.610 \\
\hline & $(0.776)$ & & $(0.788)$ & $(0.844)$ & $(0.822)$ \\
\hline \multirow[t]{2}{*}{ Independent directors } & & 0.436 & & & \\
\hline & & $(1.310)$ & & & \\
\hline Proprietary directors & & 0.566 & & & \\
\hline & & $(1.054)$ & & & \\
\hline Managerial ownership & 0.488 & 0.567 & 0.491 & 0.237 & 0.533 \\
\hline & $(2.061)$ & $(2.081)$ & $(2.083)$ & $(2.077)$ & $(2.169)$ \\
\hline Profitability & $-6.494 * * *$ & $-6.844 * * *$ & $-7.112 * * *$ & $-7.481 * * *$ & $-7.209 * * *$ \\
\hline & $(2.267)$ & $(2.394)$ & $(2.683)$ & $(2.571)$ & $(2.565)$ \\
\hline Financial expense & $0.262 * *$ & $0.320 * * *$ & $0.295 * * *$ & $0.323 * * *$ & $0.294 * *$ \\
\hline & $(0.107)$ & $(0.122)$ & $(0.113)$ & $(0.118)$ & $(0.117)$ \\
\hline Retained earnings & $-1.338^{*}$ & $-1.526^{* *}$ & $-1.644^{* *}$ & $-1.486^{* *}$ & $-1.865^{* *}$ \\
\hline & $(0.724)$ & $(0.753)$ & $(0.753)$ & $(0.740)$ & $(0.799)$ \\
\hline Total blocks*Bank power & $-3.231 * *$ & & $-3.365^{* *}$ & $-2.749 * *$ & \\
\hline & $(1.608)$ & & (1.719) & $(1.327)$ & \\
\hline PresSensit blocks*Bank power & & -19.621 & & & \\
\hline & & $(17.011)$ & & & \\
\hline PresResist blocks*Bank power & & $-12.413 * *$ & & & \\
\hline & & (7.138) & & & \\
\hline Non-financial blocks*Bank power & & 1.289 & & & \\
\hline & & $(7.781)$ & & & \\
\hline Number of blocks*Bank power & & & $1.778 * *$ & & \\
\hline & & & $(0.726)$ & & \\
\hline Herfindahl index $*$ Bank power & & & & $-1.985 * *$ & \\
\hline & & & & $(0.899)$ & \\
\hline Block $1 *$ Bank power & & & & & $-5.915 *$ \\
\hline & & & & & $(5.470)$ \\
\hline Block $2 *$ Bank power & & & & & $63.720 *$ \\
\hline & & & & & $(34.527)$ \\
\hline Block $3 *$ Bank power & & & & & $-62.806^{*}$ \\
\hline & & & & & $(36.978)$ \\
\hline CEO/Chair*Bank power & 0.813 & 0.776 & 1.429 & 1.576 & 0.971 \\
\hline & $(2.448)$ & $(2.537)$ & $(2.502)$ & $(2.605)$ & $(1.772)$ \\
\hline Proprietary director chair & $13.630 * * *$ & $11.237 * * *$ & $14.051 * * *$ & $14.971 * * *$ & $14.182 * * *$ \\
\hline & $(1.549)$ & $(2.187)$ & $(1.706)$ & $(1.603)$ & $(1.888)$ \\
\hline Outside directors *Bank power & $-5.551 *$ & & $-5.841 *$ & $-5.884 *$ & $-5.202 *$ \\
\hline & $(3.101)$ & & $(3.090)$ & $(3.081)$ & $(2.827)$ \\
\hline Independent directors*Bank power & & $\begin{array}{r}-25.769 \\
(17.613)\end{array}$ & & & \\
\hline
\end{tabular}


Bank power, Governance and Distress

\begin{tabular}{lrrrrr}
\hline Proprietary directors*Bank power & & $-32.064 * *$ & & & \\
& & $(15.566)$ & & & \\
LogTotal assets & -0.226 & $-0.252^{*}$ & $-0.258^{*}$ & -0.224 & $-0.370^{* *}$ \\
& $(0.146)$ & $(0.149)$ & $(0.157)$ & $(0.154)$ & $(0.161)$ \\
Industry controls & Yes & Yes & Yes & Yes & Yes \\
Constant & 2.208 & 1.535 & -1.400 & 0.835 & 3.215 \\
& $(0.518)$ & $(2.102)$ & $(2.230)$ & $(2.135)$ & $(2.259)$ \\
& & & & $185)$ & 184 \\
\hline Number of firms & 184 & -98.057 & -101.010 & -99.371 & -95.945 \\
Log likelihood & -104.188 & $206.61 * * *$ & $277.39 * * *$ & $327.52 * * *$ & $246.64 * * *$ \\
Model $\chi^{2}$ & $284.47 * * *$ & 0.199 & 0.213 & 0.240 \\
Pseudo $\mathrm{R}^{2}$ & 0.175 & 0.223 & 0.13 & \\
\hline
\end{tabular}

Robust standard errors in parentheses; ***;**; and * Significant at the $1 \%, 5 \%$ and $10 \%$ levels, respectively; Bank power=a dummy taking the value of 1 if bank is both lender and equity-holder, and 0 otherwise; Block ownership $=\%$ shares owned by all non-dual bank blockholders; Financial block ownership $=\%$ shares owned by non-dual bank financial blockholders; Nonfinancial block ownership $=\%$ shares owned by nonfinancial blockholders; $C E O / C h a i r$ duality =a dummy variable that takes the value of 1 for role duality, and 0 otherwise; Outside boards $=\%$ non-dual bank outside directors: Board independence $=\%$ of independent directors; Proprietary directors $=\%$ of non-dual bank proprietary directors; Managerial ownership $=\%$ shares held by executive directors; Profitability=PBIT scaled by the replacement value of total assets; Financial expense=interest paid scaled by the replacement value of total assets; Retained earnings=total retained earnings scaled by the replacement value of total assets 